\title{
Design of a Proteolytically Stable Sodium-Calcium Exchanger 1 Activator Peptide for In Vivo Studies
}

Pimthanya Wanichawan ${ }^{1,2}$, Jonas Skogestad ${ }^{1}$, Marianne Lunde ${ }^{1,2}$, Thea Parsberg Støle ${ }^{1,2}$, Maria Stensland ${ }^{3}$, Tuula A. Nyman ${ }^{3}$, Ivar Sjaastad ${ }^{1,2}$, Ole M. Sejersted ${ }^{1,2}$, Jan Magnus Aronsen ${ }^{4,5}$ and Cathrine Rein Carlson ${ }^{1,2 *}$

${ }^{1}$ Institute for Experimental Medical Research, Oslo University Hospital and University of Oslo, Oslo, Norway, ${ }^{2}$ The KG Jebsen Cardiac Research Center and Center for Heart Failure Research, University of Oslo, Oslo, Norway, ${ }^{3}$ Department of Immunology, Institute of Clinical Medicine, University of Oslo and Rikshospitalet Oslo, Oslo, Norway, ${ }^{4}$ Department of Molecular Medicine, Institute of Basic Medical Sciences, Faculty of Medicine, University of Oslo, Oslo, Norway, ${ }^{5}$ Department of Pharmacology, Oslo University Hospital Rikshospitalet, Oslo, Norway

OPEN ACCESS

Edited by:

Matteo Elia Mangoni, Centre National de la Recherche Scientifique (CNRS), France

Reviewed by:

Michael Jonathan Shattock, King's College London, United Kingdom Diego Varela, University of Chile, Chile

*Correspondence:

Cathrine Rein Carlson cathrine.carlson@medisin.uio.no

Specialty section:

This article was submitted to Pharmacology of Ion Channels and Channelopathies, a section of the journal Frontiers in Pharmacology

Received: 15 December 2020 Accepted: 14 May 2021 Published: 07 June 2021

Citation:

Wanichawan P, Skogestad J, Lunde M, Støle TP, Stensland M, Nyman TA, Sjaastad I, Sejersted OM, Aronsen JM and Carlson CR (2021)

Design of a Proteolytically Stable

Sodium-Calcium Exchanger 1 Activator Peptide for In Vivo Studies.

Front. Pharmacol. 12:638646. doi: 10.3389/fphar.2021.638646
The cardiac sodium-calcium exchanger (NCX1) is important for normal $\mathrm{Na}^{+}-$and $\mathrm{Ca}^{2+}$ homeostasis and cardiomyocyte relaxation and contraction. It has been suggested that NCX1 activity is reduced by phosphorylated phospholemman (pSer68-PLM); however its direct interaction with PLM is debated. Disruption of the potentially inhibitory pSer68-PLMNCX1 interaction might be a therapeutic strategy to increase NCX1 activity in cardiac disease. In the present study, we aimed to analyze the binding affinities and kinetics of the PLM-NCX1 and pSer68-PLM-NCX1 interactions by surface plasmon resonance (SPR) and to develop a proteolytically stable NCX1 activator peptide for future in vivo studies. The cytoplasmic parts of PLM (PLM $\mathrm{Cyt}_{\mathrm{t}}$ ) and pSer68-PLM (pSer68-PLM $\left.\mathrm{Cyt}_{\mathrm{ct}}\right)$ were found to bind strongly to the intracellular loop of NCX1 ( $\mathrm{NCX}_{\text {cyt }}$ ) with similar $K_{D}$ values of $4.1 \pm 1.0 \mathrm{nM}$ and $4.3 \pm 1.9 \mathrm{nM}$, but the $\mathrm{PLM}_{\text {cyt }}-\mathrm{NCX} 1_{\text {cyt }}$ interaction showed higher on/off rates. To develop a proteolytically stable NCX1 activator, we took advantage of a previously designed, high-affinity PLM binding peptide (OPT) that was derived from the PLM binding region in NCX1 and that reverses the inhibitory PLM (S68D)-NCX1 interaction in HEK293. We performed $\mathrm{N}$ - and C-terminal truncations of OPT and identified PYKEIEQLIELANYQV as the minimum sequence required for pSer68-PLM binding. To increase peptide stability in human serum, we replaced the proline with an N-methylproline (NOPT) after identification of $\mathrm{N}$-terminus as substitution tolerant by twodimensional peptide array analysis. Mass spectrometry analysis revealed that the halflife of NOPT was increased 17 -fold from that of OPT. NOPT pulled down endogenous PLM from rat left ventricle lysate and exhibited direct pSer68-PLM binding in an ELISA-based assay and bound to pSer68-PLM cyt $_{\text {with }} K_{D}$ of $129 \mathrm{nM}$. Excess NOPT also reduced the

\footnotetext{
Abbreviations: HEK293, human embryonic kidney; HF, heart failure; HRP, horse radish peroxidase; Ka, association rate constant; Kd, dissociation rate constant; KD, dissociation equilibrium constant; NCX1, sodium-calcium exchanger 1; NCX2, sodium-calcium exchanger 2; NCX3, sodium-calcium exchanger 3; NKA, $\mathrm{Na}^{+} / \mathrm{K}^{+}$-ATPase; NMP, N-methyl-proline; NOPT, NMP-conjugated minimal pSer68-PLM binding OPT; OPT, optimized peptide (first generation); PIP2, phosphatidylinositol 4,5-bisphosphate; PLM, phospholemman; pSer68, phosphorylated serine 68; SA chip, streptavidin coated chip; SPR, surface plasmon resonance, TAT, transactivator of transcription (cell permeable tag); TM, transmembrane; WT, wild type; XIP, exchange inhibitory peptide.
} 
PLM cyt $-\mathrm{NCX} 1_{\text {cyt }}$ interaction in an ELISA-based competition assay, but in line with that NCX1 and PLM form oligomers, NOPT was not able to outcompete the physical interaction between endogenous full length proteins. Importantly, cell-permeable NOPT-TAT increased NCX1 activity in cardiomyocytes isolated from both SHAM-operated and aorta banded heart failure (HF) mice, indicating that NOPT disrupted the inhibitory pSer68-PLM-NCX1 interaction. In conclusion, we have developed a proteolytically stable NCX1-derived PLM binding peptide that upregulates NCX1 activity in SHAM and HF cardiomyocytes.

Keywords: PLM, NCX1, disruptor peptide, NKA, cardiac, brain, peptide arrays, peptidomimetics

\section{INTRODUCTION}

The cardiac sodium $\left(\mathrm{Na}^{+}\right) /$calcium $\left(\mathrm{Ca}^{2+}\right)$ exchanger $1(\mathrm{NCX} 1)$ plays an important role in the regulation of $\mathrm{Na}^{+}$and $\mathrm{Ca}^{2+}$ homeostasis in the heart (Blaustein and Lederer, 1999; Shattock et al., 2015). Its activity is regulated by $\mathrm{Na}^{+}$and $\mathrm{Ca}^{2+}$ concentrations and the membrane potential, in addition to several protein partners. During most of the excitationcontraction-relaxation cycle, NCX1 operates in forward mode, in which it transports one $\mathrm{Ca}^{2+}$ ion out of the cell in exchange for three $\mathrm{Na}^{2+}$ ions. However, during early systole, when the membrane potential exceeds the equilibrium potential of NCX1, the reverse mode is favored (Lines et al., 2006). This unique capability of NCX1 to work in both directions, confers its ability to regulate both relaxation and contraction during the excitation-contraction-relaxation cycle.

In cardiac disease, altered NCX1 activity and $\mathrm{Na}^{+}$and $\mathrm{Ca}^{2+}$ homeostasis are often observed. The NCX1 $\mathrm{Ca}^{2+}$ removal rate may be slowed and in some pathologies it operates in reverse mode, leading to an increased cardiomyocyte $\mathrm{Ca}^{2+}$ influx and $\mathrm{Ca}^{2+}$ accumulation (Shattock et al., 2015). The intracellular $\mathrm{Ca}^{2+}$ accumulation is associated with an impaired diastolic function, accelerated myocardial necrosis, contractile failure and arrhythmias. Thus, because of its important role in the heart, NCX1 is considered to be a therapeutic target. However, it is an open question whether activation or inhibition of NCX1 would be beneficial to treat different types of heart failure (HF) (Shattock et al., 2015).

Our current understanding of NCX1 regulation in normal and pathophysiological conditions is limited. Several studies have indicated that NCX1 is modulated by $\beta$-adrenergic receptor activation, but there are conflicting reports as to whether or not protein kinase A (PKA) phosphorylates and exerts effects on NCX1 directly (Ruknudin et al., 2000; Wei et al., 2003; Ginsburg and Bers, 2005; Lin et al., 2006; Barman et al., 2011). We and others have shown that NCX1 can be phosphorylated by PKA and protein kinase $\mathrm{C}$ ( $\mathrm{PKC})$ at sites that are found in the cytoplasmic loop of NCX1 (Iwamoto et al., 1995; Iwamoto et al., 1996; Ruknudin et al., 2000; Wanichawan et al., 2011), but work in our laboratory has shown that PKA does not phosphorylate the full length cardiac NCX1 protein (Wanichawan et al., 2011).

Other components and proteins that are reported to regulate NCX1 activity are phosphatidylinositol 4,5-biphosphate (PIP2)
(He et al., 2000), the endogenous exchanger inhibitory peptide (XIP) region (Matsuoka et al., 1997; Maack et al., 2005; Gök et al., 2020), calpain (Wanichawan et al., 2014), protein phosphatase 1 (PP1) (Hafver et al., 2016), and phospholemman (PLM) (Ahlers et al., 2005). PLM, which contains 3 PKA/PKC phosphorylation sites in its C-terminus (Walaas et al., 1994; Fuller et al., 2009), has been reported to be an endogenous inhibitor of NCX1 (Ahlers et al., 2005; Zhang et al., 2006; Wang et al., 2014). However, the concept of PLM regulation of NCX1 is a matter of debate. Although no transfer of fluorescence resonance energy (FRET) was detected between PLM and NCX1 that were tagged with fluorescent proteins (Bossuyt et al., 2006), we and others have shown that PLM co-precipitates with NCX1 in both cardiac (Ahlers et al., 2005; Wang et al., 2014; Wanichawan et al., 2016) and brain tissue (Wanichawan et al., 2016). It has further been shown that PLM binds directly to two regions of NCX1 that contain PASKT and QKHPD sequences (Zhang et al., 2011; Wanichawan et al., 2016) and that PLM is able to inhibit NCX1 activity when it is phosphorylated at serine 68 (pSer68) [or mutated to an aspartic (S68D) or glutamic acid (S68E)] (Zhang et al., 2006; Wang et al., 2014; Wanichawan et al., 2016). The level of pSer68-PLM appears to be upregulated in some animal HF models (Bossuyt et al., 2005; Hafver et al., 2016), but not in others (Shattock et al., 2015).

The effect of pSer68-PLM on possible NCX1 activity and $\mathrm{Ca}^{2+}$ handling is complex as pSer68-PLM concomitantly relieves the inhibitory effect on the $\mathrm{Na}^{+} / \mathrm{K}^{+}$-ATPase (NKA) (Cheung et al., 2013; Shattock et al., 2015; Yap et al., 2021), which leads to a decreased intracellular $\mathrm{Na}^{+}$level, which in turn rather increases the driving force for $\mathrm{Ca}^{2+}$ efflux through NCX1. Whereas the cytoplasmic tail of the PLM oligomer is reported to bind to NCX1, the transmembrane domain of the PLM monomer binds to NKA (Shattock et al., 2015). Since PLM is an important regulator of NKA and possibly of NCX1, it is considered as a therapeutic target in cardiac disease, but few interventions are available.

In the present study, we aimed to analyze the binding affinities and kinetics of the possible PLM/pSer68-PLM-NCX1 interactions by surface plasmon resonance (SPR) and to develop a proteolytically stable, NCX1 activator peptide for future in vivo studies. For the latter, we took advantage of having access to a previously optimized PLM binding peptide (OPT, 20-mer). This peptide is derived from the QKHPDcontaining region of NCX1 and has been shown to exhibit an 
8-fold increase in pSer68-PLM binding compared with NCX1, and it reverses PLM (S68D) inhibition of exogenously expressed NCX1 in HEK293 cells (Wanichawan et al., 2016). The final developed NOPT peptide (16-mer), substituted with an N-methyl proline, showed a 17-fold increased stability in human serum compared with OPT, precipitated endogenous PLM from left ventricle lysate, exhibited a direct pSer68-PLM binding, outcompeted the direct $\mathrm{PLM}_{\text {cyt }}-\mathrm{NCX} 1_{\text {cyt }}$ interaction and increased endogenous NCX1 activity when it was introduced as a cell-permeable peptide into adult cardiomyocytes that were isolated from SHAM-operated and aorta banded HF mice.

\section{MATERIALS AND METHODS}

\section{Peptide Array, Synthesis and Overlay}

Peptides on cellulose membranes were synthesized using a Multipep automated peptide synthesizer (INTAVIS Bioanalytical Instruments AG, Koeln, Germany) (Frank, 1992, Frank, 2002). Peptides in solution were synthesized (listed below) at $>80 \%$ purity by Genscript (Corporation, Piscataway, NJ, United States). For some of the peptides a cell-permeable TAT (RKKRRQRRR) or a biotin tag was included at either $\mathrm{N}$ - or $\mathrm{C}$-terminus with or without an ahx-linker in between to avoid any potential steric hindrance.

PLM $_{\text {cyt }}$ KRCRCKFNQQQRTGEPDEEEGTFRSSIRRLSSRRR pSer68-PLM cyt $_{\text {: KRCRCKFNQQQRTGEPDEEEGTFRSSIRR }}$ LPSSRRR

OPT: YHPYKEIEQLIELANYQVLS

Mini-OPT: PYKEIEQLIELANYQV

NOPT: NMP-YKEIEQLIELANYQV

Scrambled control: VYEKNYLLLPAIEQEQSHIY (negative control peptide)

OPT (E6G): YHPYKGIEQLIELANYQVLS (negative control peptide)

OPT (1Y4A): YHPYKEIEQLIELANAQQVLS (negative control peptide)

Anti-NCX1 blocking peptide (amino acids 655-672): CGQPVFRKVHARDHPIPST

Peptide array membranes were blocked in $1 \%$ casein for $2-4 \mathrm{~h}$ and overlaid with $5 \mu \mathrm{M}$ of biotinylated pSer68-PLM peptide in $1 \%$ casein overnight at $4^{\circ} \mathrm{C}$. The membranes were then washed three times for $10 \mathrm{~min}$ in TBS-T before incubation with antibiotin-horseradish peroxidase (HRP) for $1 \mathrm{~h}$ (see Antibodies and Recombinant Protein). Peptide-bound spots were detected as described in the immunoblotting section.

\section{Sample Preparation for Mass Spectrometry Analysis}

Peptide stability was analyzed by incubating the peptide $(300 \mu \mathrm{M})$ in $30 \%$ human serum (diluted in phosphate-buffered saline; PBS) (21792, Innovative research, MI, United States) at $37^{\circ} \mathrm{C}$. Aliquots of $50 \mu \mathrm{l}$ were collected at different time points $(0-48 \mathrm{~h})$ and thereafter trichloroacetic acid (TCA) was added to a final concentration of $5 \%$ to stop the reaction. The aliquots were kept at $-20^{\circ} \mathrm{C}$ before centrifugation at $13,000 \mathrm{~g}$ for $15 \mathrm{~min}$ to remove the serum proteins. The supernatants were stored at $-20^{\circ} \mathrm{C}$ until the mass spectrometry analysis.

\section{Mass Spectrometry Analysis}

The peptides were purified using $\mu \mathrm{C} 18$ tips (Pierce C18 Tips, $100 \mu \mathrm{l}$ ) according to manufacturer's instructions. $142 \mathrm{fmol}$ purified peptide sample was analyzed by a nEASY-LC coupled to QExactive/ QExactive Plus with EASY Spray PepMap ${ }^{\circledR}$ RSLC, C18, $2 \mu$, $100 \AA, 75 \mu \mathrm{m} \times 25$ column using a $60 \mathrm{~min}$ separation gradient (0-30\% acetonitrile). MS raw files were submitted to MaxQuant software version 1.5.3.8 (Cox and Mann, 2008) for protein and peptide identification and intensity-based quantification. The search parameters were: First search error window of $20 \mathrm{ppm}$ and main search error of $4.5 \mathrm{ppm}$; Unspecific enzyme; Minimal unique peptides 1; and FDR 0.01 (1\%) for peptide and protein identification. Minimum and maximum peptide length for unspecific search were set to 8 and 25, respectively. The Uniprot human database was used (download from UniProt Sept. 2015) including the sequence for NOPT as the search database.

\section{Preparation of Rat Left Ventricle Lysates}

Left ventricle lysates from 3-6 rats were prepared by using the TissueLyser II from Qiagen, Germantown, MD, United States. Briefly, frozen left ventricle tissue from rat heart $(\sim 30 \mathrm{mg})$ was homogenized with ice-cold RH lysis buffer (PBS with $0.5 \%$ Triton and $0.1 \%$ Tween) supplemented with PhosSTOP tablets (4906837001, Roche Diagnostics, Indianapolis, IN, United States) and protease inhibitors (11836170001, Complete Mini EDTA-free tablets, Roche Diagnostics). The tissue samples were homogenized twice for $100 \mathrm{~s}$ at $30 \mathrm{~Hz}$ and then incubated on ice for $30 \mathrm{~min}$. Supernatants were collected by centrifugation at $4,000 \mathrm{rpm}$ for $10 \mathrm{~min}$ at $4^{\circ} \mathrm{C}$ and thereafter stored at $-80^{\circ} \mathrm{C}$. For IP experiments (Figures 3G, 4B), left ventricular tissue was pulverized in a mortar with liquid nitrogen, then added into lysis buffer $(20 \mathrm{mM}$ Hepes, $\mathrm{pH} 7.5$, $150 \mathrm{mM} \mathrm{NaCl}, 1 \mathrm{mM}$ EDTA, $0.5 \%$ Triton) with protease inhibitors and homogenized $3 \times 1 \mathrm{~min}$ at $0^{\circ} \mathrm{C}$. Supernatants were collected by centrifugation at $32,000 \mathrm{rpm}$ for $60 \mathrm{~min}$ at $4^{\circ} \mathrm{C}$ and thereafter stored at $-80^{\circ} \mathrm{C}$.

\section{Pull-Down Assay With Biotinylated Peptides}

Biotinylated peptide $(8 \mu \mathrm{M}$ final concentration $)$ was incubated with $25 \mu$ of monoclonal anti-biotin conjugated beads (A-1559, Sigma-Aldrich, St. Louis, MO, United States) in $100 \mu \mathrm{l}$ of $1 \times \mathrm{PBS}$ for $2 \mathrm{~h}$ at $4^{\circ} \mathrm{C}$ with rotation. The beads were then washed one time with PBS, centrifuged at 1,000 rcf for $30 \mathrm{~s}$ at $4^{\circ} \mathrm{C}$, and $200 \mu \mathrm{l}$ of left ventricle lysate was added. The tubes were incubated for $2 \mathrm{~h}$ at $4^{\circ} \mathrm{C}$ with gentle rotation, and thereafter washed once in IP buffer $(20 \mathrm{mM}$ HEPES, $\mathrm{pH}$ 7.5, $150 \mathrm{mM} \mathrm{NaCl}, 1 \mathrm{mM}$ EDTA and $1 \%$ Triton X-100). Finally, the samples were boiled in SDS loading buffer for 5 min at $96^{\circ} \mathrm{C}$ and analyzed by immunoblotting.

\section{Immunoprecipitation}

Left ventricle lysate was incubated with the specific antibodies $(2 \mu \mathrm{g} / \mathrm{IP}), 50 \mu \mathrm{l}$ protein PLUS A/G agarose beads (sc-2003, 


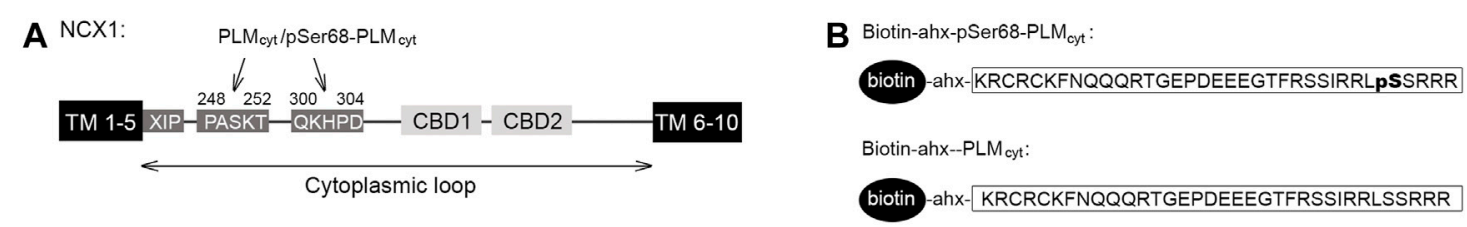

C His-TF-NCX1 $1_{\text {cyt }}$ binding to biotin-ahx-pSer68-PLM cyt $_{\text {(single-cycle) }}$

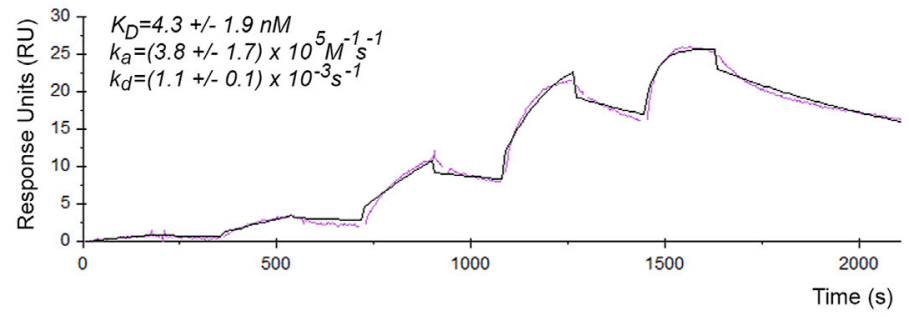

D His-TF-NCX1 $1_{\text {cyt }}$ binding to biotin-ahx-PLM cyt $_{\text {(single-cycle) }}$

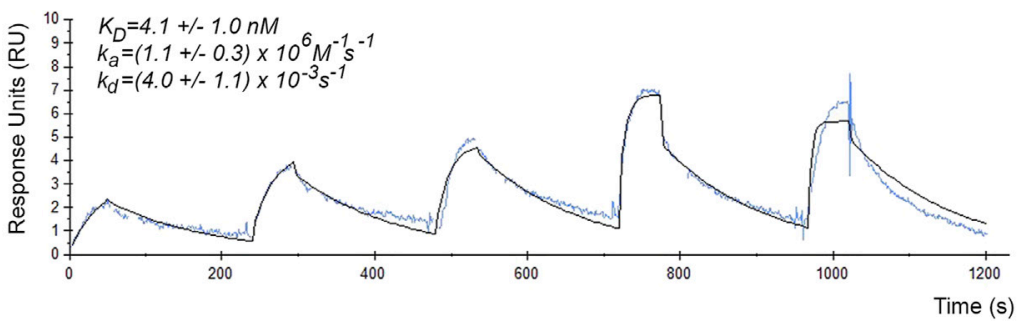

FIGURE 1 | Binding affinities and kinetics of the pSer68-PLM-NCX1 and PLM-NCX1 interactions. (A) Illustration of the domain organization in NCX1. NCX1 contains 10 transmembrane (TM) domains, among which a large cytoplasmic loop between TM domains 5 and 6 , that plays a regulatory role. The two PASKT- and QKHPD-containing regions in the cytoplasmic loop have been shown to bind directly to PLM/pSer68-PLM (Zhang et al., 2011; Wanichawan et al., 2016). XIP has been shown to bind to another site in the cytoplasmic loop, leading to NCX1 inactivation (Matsuoka et al., 1997; Maack et al., 2005; Gök et al., 2020). Binding of Ca ${ }^{2+}$ to CBD1 and CBD2 (calcium binding domain 1 and 2) leads to increased NCX1 activation. (B) Illustration of the two biotin-ahx-pSer68-PLM cyt $_{\text {and biotin-ahx-PLM }}$ cyt peptides that were used in Panel (C,D), Figures 2B-E, 3F, and Supplementary Figure S1A. An ahx-linker was included to avoid any potential steric hindrance. SPR analyses of (C) biotin-ahx-pSer68-PLM cyt $_{\text {and }}$ (D) biotin-ahx-PLM cyt immobilized on SA chips and recombinant His-TF-NCX1 $1_{\text {cyt }}$ protein injected at a range of concentrations over the chips. Red and blue show the experimental data in $C(n=3)$ and $D(n=5)$ (single cycles), respectively, whereas the black shows the fit (mathematical model).

Santa Cruz) and with or without presence of $100 \mu \mathrm{M}$ NOPTTAT or OPT overnight at $4^{\circ} \mathrm{C}$. Immunocomplexes were washed twice in IP buffer (20 mM Hepes, pH 7.5, $150 \mathrm{mM} \mathrm{NaCl}, 1 \mathrm{mM}$ EDTA, $1 \%$ Triton), centrifuged at $3,000 \mathrm{~g}$ for $1 \mathrm{~min}$ at $4^{\circ} \mathrm{C}$ and boiled in SDS loading buffer before the immunoblot analyses were undertaken. Equal amount of mouse IgG (sc-2025, Santa Cruz) or a custom made anti-NCX1 blocking peptide (CGQPVFRKVHARDHPIPST) incubated with anti-NCX1 prior to immunoprecipitation (Hafver et al., 2016) was used as negative control.

\section{Immunoblotting and Densitometry Analysis}

The pull-down samples were separated on $4-15$ or $15 \%$ SDSPAGE Criterion Tris-HCl Gel (\#3450027 and \#3450020, BioRad Laboratories, Inc., Hercules, CA, United States) and transferred onto a PVDF membrane (1704157, Trans-Blot Turbo Mini PVDF Transfer Packs, Biorad Laboratories) using the Trans-Blot Turbo Transfer System (Biorad Laboratories). The PVDF was blocked in $1 \%$ casein or $5 \%$ milk in TBS-T for $60 \mathrm{~min}$ at room temperature
(RT), and thereafter incubated with gentle agitation with primary antibody overnight at $4^{\circ} \mathrm{C}$. After incubation with the primary antibody, the membrane was washed three times for $10 \mathrm{~min}$ in TBS-T and further incubated with the secondary antibody (see antibody section) and washed again. The chemiluminescence signals was developed using ECL Plus (RPN2232, GE HealthCare, United States) and detected by a LAS 4000 imager (Fujifilm, Tokyo, Japan). The densitometry analyses were performed using ImageJ $(\mathrm{NIH})$.

\section{Antibodies and Recombinant Protein}

Immunoblotting and IPs were carried out using anti-biotin-HRP (1: 5,000, A0185, Sigma-Aldrich, St. Louis, MO, United States), anti-PLM (anti-FXYD1, ab76597, 1:4,000, Cambridge, MA, United States), anti-NCX1 (1:1,000, custom made by Genscript Corp., Piscataway, NJ, United States, epitope: GQPVFRKVHARDHPIPST, mapped in (Wanichawan et al., 2011), anti-NKA (1:2,500, 05-369, Sigma-Aldrich) and antiserine 68 phosphorylated PLM [pSer68-PLM, 1:1,000 (Fuller 
et al., 2009)]. Anti-rabbit IgG HRP (1:2,500 or 1:3,000, NA934, GE HealthCare, United States) and anti-mouse IgG HRP (1:3,000, NA931, GE HealthCare, United States) were used as secondary antibodies. Recombinant protein that covered the NCX1 cytoplasmic part added N-terminal histidine (HIS) and trigger factor (TF) tags to stabilize the protein (HIS-TF-NCX1 $1_{\text {cyt }}$ ) was custom made by Genscript Corp., (Piscataway, NJ, United States).

\section{Enzyme-Linked Immunosorbent Assay}

A 96-well ELISA microplate was coated with $10 \mu \mathrm{g}$ of $\mathrm{PLM}_{\text {cyt }}$ or

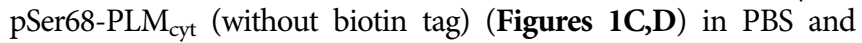
agitated gently overnight at $4^{\circ} \mathrm{C}$. After this, each well was washed with PBS supplemented with $0.05 \%$ Tween (PBS-T), blocked with $0.5 \%$ gelatine (G-1890, Sigma) for $1 \mathrm{~h}$ at RT and incubated with $5 \mu \mathrm{l}$ of the given peptides (final concentration: $50 \mu \mathrm{M}$ ) for $2 \mathrm{~h}$ at $37^{\circ} \mathrm{C}$ with gentle agitation. Each well was then washed five times with PBS-T, incubated with anti-biotin-HRP for $30 \mathrm{~min}$ at RT, and washed again five times with PBS-T, before incubation with $100 \mu \mathrm{l}$ of the Ultra TMB substrate solution (34028, Thermo Fisher Scientific, Waltham, MA, United States) for 15-30 min at RT with gentle agitation (blue color development). In order to stop the reaction, $2 \mathrm{~N}$ hydrochloric acid $(\mathrm{HCl})$ was added into each well (yellow color). The absorbance of each sample was measured at $450 \mathrm{~nm}$ (Hidex Sense multimodal microplate reader, Åbo, Finland). For the competition experiment (Figure 1F), the microplate was coated with $10 \mu \mathrm{g} / \mathrm{ml}$ recombinant HIS-TF-NCX1 $1_{\text {cyt }}$ protein before $0.5 \mu \mathrm{l}$ biotin-ahx-PLM peptide (final concentration: $5 \mu \mathrm{M}$ ) was incubated with or without $10 \mu \mathrm{l}$ NOPT $(100 \mu \mathrm{M}$, without any biotin tag) for $2 \mathrm{~h}$ at $37^{\circ} \mathrm{C}$ with gentle agitation.

\section{Surface Plasmon Resonance Analyses}

The SPR analyses were performed using Biacore X100 analyser (Biacore Inc., Uppsala, Sweden). The biotinylated pSer68-PLM ${ }_{\text {cyt }}$ or $\mathrm{PLM}_{\text {cyt }}$ peptides (ligand) were immobilized on streptavidin (SA) chips (BR100032, GE Healthcare Life Sciences) at 50-200 resonance units (RU) after the chip was conditioned through application of three consecutive $1 \mathrm{~min}$ injections of $1 \mathrm{x}$ Biacore running buffer (BR100826, GE Healthcare Life Sciences). NOPTTAT or recombinant His-TF-NCX1 $1_{\text {cyt }}$ (analyte) dialyzed into the running buffer was diluted over a range of concentrations (NOPT-pSer68-PLM cyt $_{\text {: }} 4.5-175$ nM; His-TF-NCX1 $1_{\text {cyt }}$-pSer68$\mathrm{PLM}_{\text {cyt }}$ : $0.6-50 \mathrm{nM}, 6.25-100 \mathrm{nM}$, and $3.12-50 \mathrm{nM}$; His-TF$\mathrm{NCX}_{\text {cyt }}-\mathrm{PLM}_{\text {cyt }}$ : 9.38-150 nM, $12.5-200 \mathrm{nM}, 18.75-300 \mathrm{nM}$, 4.69-75 $\mathrm{nM}$ and $9.38-150 \mathrm{nM}$ ), and injected over the sensor surface at a flow rate of 30 or $100 \mu \mathrm{l} / \mathrm{min}$ (to avoid mass transport limitations) for $180 \mathrm{~s}$. The dissociation time was set at $600 \mathrm{~s}$. The obtained sensorgrams were analyzed through use of Biacore X100 evaluation software and curve fitting was performed with the assumption of one-to-one binding (Langmuir) or steady state affinity.

\section{Heart Failure Model in Mice}

8 weeks old C57BL6/J mice were randomized to SHAM or an aortic banding $(\mathrm{AB})$ operation using o-rings (ORAB) as previously described (Melleby et al., 2018). Mice were anesthetized in a combination of $5 \%$ isoflurane and $95 \% \mathrm{O}_{2}$, before endotracheal intubation and ventilation using a MiniVent rodent ventilator
(Harvard Apparatus, United States). Left sided hemothoracotomy in the third intercostal space was performed, before dissection and placement of the o-ring around the ascending aorta. Animals were allowed to recover, and post-operative analgesia was achieved by injections of buprenorphine in accordance with the institutional guidelines. Animal experiments was approved by the Norwegian National Animal Research Committee (FDU 7040).

\section{Isolation of Adult Mice Cardiomyocytes}

Cardiomyocytes were isolated based on a similar protocol as recently described (Ackers-Johnson et al., 2016). Mice were anesthetized and mask ventilated with a combination of $3 \%$ isoflurane and $97 \% \mathrm{O}_{2}$. Deep surgical anesthesia was confirmed by abolished pain reflexes. The chest was opened, before the descending aorta and inferior caval vein were cut. Then $7 \mathrm{ml}$ of buffer A (in mM: HEPES 25, $\mathrm{NaCl} \mathrm{130,} \mathrm{KCl} 5.4, \mathrm{NaH}_{2} \mathrm{PO}_{4} 0.4$, $\mathrm{MgCl}_{2}$ 0.5, D-glucose 22, $\mathrm{pH} 7.4$ ) with $5 \mathrm{mM}$ EDTA was injected into the right ventricle. Thereafter, the aorta was clamped and the heart was excised. $10 \mathrm{ml}$ of the buffer solution and thereafter $3 \mathrm{ml}$ of the buffer solution without EDTA were injected into the left ventricle over 2-5 min. Then preheated solution A containing $0.8 \mathrm{mg} / \mathrm{ml}$ collagenase II was injected into the left ventricle over $\sim 20 \mathrm{~min}$. The atria and right ventricle were removed, and the cardiomyocytes were isolated according to the same procedure as described for the Langendorff-based isolation of rat cardiomyocytes (described further below).

\section{$\mathrm{Ca}^{2+}$ Transients, SR $\mathrm{Ca}^{2+}$ Load and NCX Activity Measurements}

Isolated cardiomyocytes were loaded for $10 \mathrm{~min}$ with $5 \mu \mathrm{M}$ fluo- 4 AM ester (Molecular Probes, Eugene, OR, United States) at RT. The superfusate contained (mM): $\mathrm{NaCl} 140$, HEPES 5, $\mathrm{KCl} 5.4$, $\mathrm{CaCl}_{2} 1, \mathrm{MgCl}_{2}$ 0.5, D-glucose 5.5 and $\mathrm{NaH}_{2} \mathrm{PO}_{4}$ 0.4. The $\mathrm{pH}$ was adjusted to 7.4. The cells were loaded with either the TATconjugated NOPT $(1 \mu \mathrm{M})$ or the TAT-conjugated scrambled control peptide $(1 \mu \mathrm{M})$ for $20 \mathrm{~min}$ at $\mathrm{RT}$. The peptides were also added to the superfusate. Whole-cell $\mathrm{Ca}^{2+}$ transients were recorded in field stimulated cardiomyocytes at $0.5 \mathrm{~Hz}(2.5 \mathrm{~ms}$ bipolar pulses) and $37^{\circ} \mathrm{C}$ with Cairn Research Optoscan Monochromator (excitation $485 \mathrm{~nm}$, emission $515 \mathrm{~nm}$ long pass) (Cairn Research Ltd., United Kingdom). Regular $\mathrm{Ca}^{2+}$ transients were recorded for at least $3 \mathrm{~min}$ per cell, before the field stimulation was stopped and $10 \mathrm{mM}$ caffeine was added. Background fluorescence was recorded for each cell. $\mathrm{Ca}^{2+}$ transients amplitude and $\mathrm{SR} \mathrm{Ca}^{2+}$ load was calculated as maximal fluorescence $(\mathrm{F})$ divided on resting fluorescence $\left(\mathrm{F}_{0}\right)$ on field stimulated and caffeine evoked $\mathrm{Ca}^{2+}$ transients, respectively (See Figure 4I for illustration of protocol details). Tau values were obtained by mono-exponential fitting of the $\mathrm{Ca}^{2+}$ extrusion phase from regular transients $(\tau)$ and caffeine transients ( $\left.\tau_{\text {caff }}\right)$ after rapid applications of $10 \mathrm{mM}$ caffeine. The NCX rate constant was calculated as: $1 / \tau_{\text {caff }}$ (Díaz et al., 1997), as the non SERCA2, non-NCX mediated $\mathrm{Ca}^{2+}$ removal was considered negligible. 
A Biotin-ahx-pSer68-PLM cyt $_{\text {: }}$

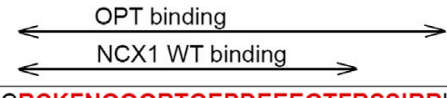

Extr TM KRCRCKFNQQQRTGEPDEEEGTFRSSIRRLPSSRRR

D Biotin-pSer68-PLM cyt overlay

YHPYKEIEQLIELANYQVLS

YHPYKEIEQLIELANYQVLS

HPYKEIEQLIELANYQVL

PYKEIEQLIELANYQV $\longleftarrow$ mini-OPT (16aa)

YKEIEQLIELANYQ

KEIEQLIELANY

EIEQLIELAN

IEQLIELA

EQLIEL

QLIE

LI
B Biotin-pSer68-PLMcyt overlay

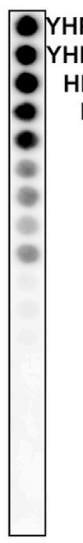

C Biotin-pSer68-PLMcyt overlay

YHPYKEIEQLIELANYQVLS

YHPYKEIEQLIELANYQVLS

YHPYKEIEQLIELANYQVL

YHPYKEIEQLIELANYQV

YHPYKEIEQLIELANYQ

YHPYKEIEQLIELANY

YHPYKEIEQLIELAN

YHPYKEIEQLIELA

YHPYKEIEQLIEL

YHPYKEIEQLIE

YHPYKEIEQL

YHPYKEIEQL

YHPYKEIEQ

YHPYKEIE

YHPYKEI

YHPYKE

YHPYK

YHPY

YHP

E Biotin-pSer68-PLM cyt overlay

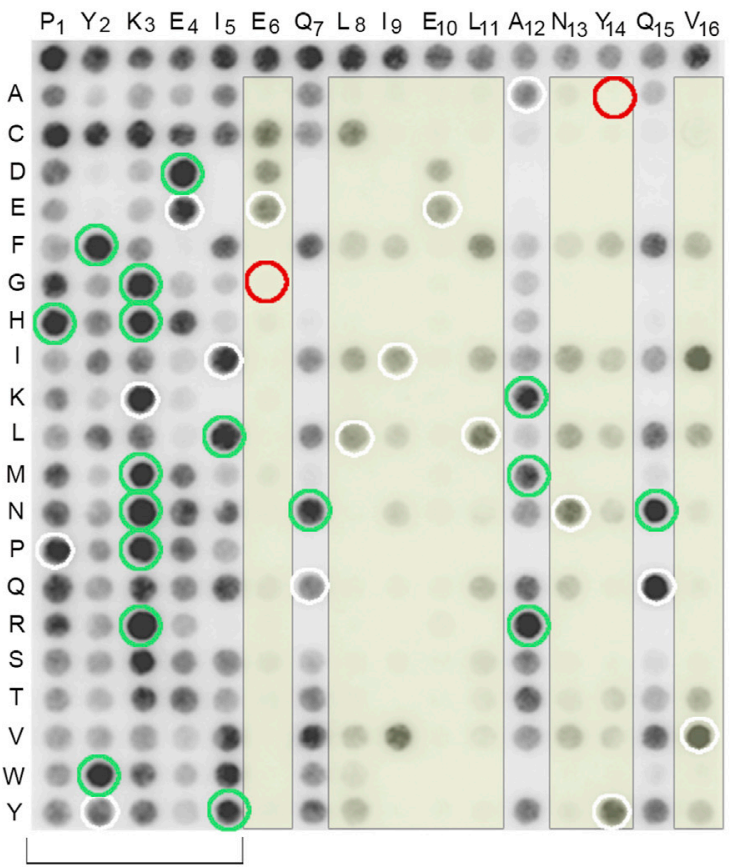

substitutions more

favorable in $\mathrm{N}$-terminus

FIGURE 2 | Identification of the minimal PLM binding sequence in OPT and of the N-terminus as substitution tolerant. (A) Illustration of the NCX1 and OPT binding sequences in PLM and pSer68-PLM cytoplasmic parts (the latter in red) (Wanichawan et al., 2016). (B) N-terminal, (C) C-terminal or (D) both N- and C- terminal truncations of the 20-mer OPT peptide (Wanichawan et al., 2016) were synthesized on membranes and overlaid with biotin-pSer68-PLM. Biotin-pSer68-PLM binding was detected with a monoclonal anti-biotin-HRP conjugated antibody. The minimal pSer68-PLM binding sequence was the 16-mer PYKEIEQLIELANYQV (miniOPT) as indicated in (D). (E) Amino acid substitutions of mini-OPT by two-dimensional peptide arrays aimed to identify modifiable positions. Biotin-pSer68-PLM binding was detected with a monoclonal anti-biotin-HRP conjugated antibody. Each residue in the mini-OPT sequence is written as a single-letter code above the array, whereas substitutions are given as single-letter codes to the left (vertically). The first row of the array shows biotin-pSer68-PLM binding to mini-OPT ( $n=16)$. White circles show biotin-pSer68-PLM binding to mini-OPT dispersed through the array (internal control peptides, $n=16$ ). Thus, in total, 32 spots showed biotin-pSer68-PLM binding to mini-OPT. Green circles indicate 17 substitutions that apparently enhanced peptide binding to biotin-pSer68-PLM. The E6G and Y14A substitutions (red circles) abolished pSer68-PLM binding and were used as negative control peptides in the pull down experiment in Figure $\mathbf{3 C}$. The yellow boxes indicate positions that were less substitution tolerant than the others. 


\section{Isolation of Adult Rat Cardiomyocytes}

Male Wistar rats were anesthetized in a chamber using inhalable isoflurane (Abbott Scandinavia Ab, Solna, Sweden), and $150 \mathrm{IE}$ heparin was administrated intravenously for post-excision thrombosis prophylaxis. The heart was excised and immediately cooled in $0.9 \% \mathrm{NaCl}$ at $4^{\circ} \mathrm{C}$. The aorta was cannulated and the coronary arteries were retrogradely perfused in a modified Langendorff setup with buffer A (in mM: HEPES 25, $\mathrm{NaCl} 130, \mathrm{KCl} 5.4, \mathrm{NaH}_{2} \mathrm{PO}_{4} 0.4, \mathrm{MgCl}_{2} 0.5$, D-glucose $22, \mathrm{pH} 7.4$ ) at $37^{\circ} \mathrm{C}$ for $2-4 \mathrm{~min}$, then with buffer A containing $0.8 \mathrm{~g} / \mathrm{L}$ collagenase II (Worthington Biochemical Corporation, United States) and $6.7 \mu \mathrm{M} \mathrm{CaCl}_{2}$ for $18-22 \mathrm{~min}$. Atria and the right ventricular free wall were removed before the left ventricle was cut into small pieces in 8-10 $\mathrm{ml}$ of the perfusate containing $500 \mu \mathrm{l} 2 \% \mathrm{BSA}$, and mechanically isolated by careful pipetting with a Pasteur pipette for $1 \mathrm{~min}$. The cardiomyocyte suspension was filtered through a nylon mesh $(200 \mu \mathrm{m})$ (Burmeister), and left at RT for sedimentation. Immediately following sedimentation $(\sim 5 \mathrm{~min})$, the supernatant was removed. The cardiomyocytes were washed three times in buffer A containing 1) $0.1 \% \mathrm{BSA}$ and $0.1 \mathrm{mM} \mathrm{CaCl}_{2}$,2) $0.1 \%$ BSA and $0.2 \mathrm{mM} \mathrm{CaCl}_{2}$, and 3) $0.05 \% \mathrm{BSA}$ and $0.5 \mathrm{mM} \mathrm{CaCl}_{2}$.

\section{$\mathrm{Na}^{+} / \mathrm{K}^{+}$-ATPase Activity Measurements}

Ventricular rat myocytes were voltage clamped using continuous mode on an Axoclamp 2A amplifier and pCLAMP software (Axon Instruments, CA, United States). We used pipettes with moderately low resistance $(2-3 \mathrm{M} \Omega)$ for a series resistance of 5-9 $\mathrm{M} \Omega$. The signal was sampled at $10 \mathrm{kHz}$ and filtered with a low-pass filter before analysis. All amplifier and program settings were held constant during and between experiments. The cells were perfused at $37^{\circ} \mathrm{C}$, and the perfusion system was placed very close to the cells, allowing rapid changes of solutions. We used an internal solution containing (in $\mathrm{mM}$ ) (modified from (Despa and Bers, 2003): $\mathrm{NaCl} 20, \mathrm{KCl} 30$, K-Aspartate 80, TEA-Cl 20, HEPES 10, MgATP 5, $\mathrm{MgCl}_{2} 0.7$ (free $\mathrm{Mg}^{2+} 1 \mathrm{mM}$ using Maxchelator, Stanford), BAPTA 3, $\mathrm{CaCl}_{2} 1.15$ (free $\mathrm{Ca}^{2+} 150 \mathrm{nM}$ ), $\mathrm{pH}=7.2$ (adjusted with $\mathrm{KOH}$ ). $30 \mu \mathrm{M}$ of OPT or the scrambled control peptide were added to the internal solution. After reaching whole-cell access, the cells were dialyzed for at least $4 \mathrm{~min}$ at $-20 \mathrm{mV}$. Myocytes were patched in the following solution (in $\mathrm{mM}$ ): $\mathrm{NaCl}$ 140, HEPES 5, $\mathrm{KCl} 5.0, \mathrm{CaCl}_{2}$ 1.0, $\mathrm{MgCl}_{2}$ 0.5, D-glucose 5.5, $\mathrm{NaH}_{2} \mathrm{PO}_{4} 0.4, \mathrm{pH}$ adjusted to 7.4 with $\mathrm{NaOH}$. Solutions were switched after reaching whole-cell access to a solution containing (in $\mathrm{mM}$ ): $\mathrm{NaCl}$ 20, NMDG 110, D-glucose 10, HEPES 5, TrisCl (or KCl) 15, $\mathrm{NiCl}_{2} 5, \mathrm{BaCl}_{2}$ 2, $\mathrm{MgCl}_{2} 1, \mathrm{pH}$ adjusted to 7.4 with $\mathrm{HCl}$. Symmetrical $\mathrm{Na}^{+}$ solutions were used to minimize the effects of intracellular $\mathrm{Na}^{+}$gradients. $\mathrm{I}_{\mathrm{NKA}}$ was elicited by rapidly switching from a solution containing $0 \mathrm{mM} \mathrm{K}^{+}$to a solution containing $15 \mathrm{mM}$ $\mathrm{K}^{+}$; $\mathrm{I}_{\mathrm{NKA}}$ was interpreted as the peak $\mathrm{K}^{+}$-sensitive current. Voltage ramp protocols were applied before and immediately after activation of $\mathrm{I}_{\mathrm{NKA}}$. Cardiomyocytes were depolarized from $-20 \mathrm{mV}$ to $+70 \mathrm{mV}$ for $50 \mathrm{~ms}$, then hyperpolarized to $-120 \mathrm{mV}\left(\mathrm{dV} / \mathrm{dt}=380 \mathrm{mV} \mathrm{s}^{-1}\right)$, and back to $-20 \mathrm{mV}$. The difference between the ramp after activation of $\mathrm{I}_{\mathrm{NKA}}$ and the baseline ramp defined the $\mathrm{I}_{\mathrm{NKA}}$-voltage relationship. All currents were standardized by relating the absolute current $(\mathrm{pA})$ to the cell size $(\mathrm{pF})$.

\section{Ethics}

All animal work was performed at the Institute for Experimental Medical Research, Oslo University Hospital, Norway. Animal handling was preapproved by the Norwegian National Animal Research Committee (FOTS ID 3820 for rats, and FOTS ID 7040 for mice) and conformed to the Guide for the Care and Use of Laboratory Animals (National Institutes of Health Publication 8523, revised 2011).

\section{RESULTS}

\section{Surface Plasmon Resonance Analyses of the PLM-NCX1 and pSer68-PLM-NCX1 Interactions}

To our knowledge, the binding affinities and kinetics of the possible PLM-NCX1 and PSer68-PLM-NCX1 interactions have not been investigated before. The cytoplasmic tails of PLM $\left(\mathrm{PLM}_{\mathrm{cyt}}\right)$ and pSer68-PLM (pSer68-PLM $\left.\mathrm{cyt}_{\mathrm{ct}}\right)$ are reported to bind directly to two PASKT- and QKHPD-containing regions in the cytoplasmic loop of $\mathrm{NCX1}\left(\mathrm{NCX}_{\mathrm{cyt}}\right)$ (illustrated in Figure 1A) (Zhang et al., 2011; Wanichawan et al., 2016).

To measure the binding affinities and kinetics of the pSer68PLM-NCX1 interaction, a biotinylated peptide that covered

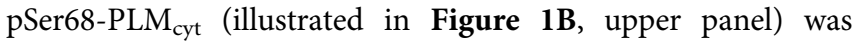
immobilized on a SA chip, and a range of concentrations of a recombinant polypeptide that covered $\mathrm{NCX} 1_{\text {cyt }}$ was injected over the chip. The result was analyzed by fitting with a 1:1 interaction model (Langmuir). The $\mathrm{K}_{\mathrm{D}}$ for the pSer68-PLM $\mathrm{Cyt}_{\mathrm{cy}}-\mathrm{NCX} 1_{\mathrm{cyt}}$ interaction was $4.3 \pm 1.9 \mathrm{nM}$, with an association rate constant $\left(\mathrm{k}_{\mathrm{a}}\right)=(3.8 \pm 1.7) \times 10^{5} \mathrm{M}^{-1} \mathrm{~s}^{-1}$ and a dissociation rate constant $\left(\mathrm{k}_{\mathrm{d}}\right)=(1.1 \pm 0.1) \times 10^{-3} \mathrm{~s}^{-1}$ (Figure 1C). These results indicated a strong pSer68-PLM-NCX1 interaction.

NCX1 binding to PLM is thought to be independent of the phosphorylation status of the serine 68 (Wanichawan et al., 2016) Therefore, we also immobilized biotinylated PLM $_{\text {cyt }}$ (illustrated in Figure 1B, lower panel) and injected a range of recombinant $\mathrm{NCX}_{\mathrm{cyt}}$ over the SA chip. Biotin-ahx-PLM $\mathrm{Pyt}_{\mathrm{cy}}$ was found to bind with similar affinity to $\mathrm{NCX1}_{\text {cyt }}(4.1 \pm 1.0 \mathrm{nM})$ as the pSer68-PLM ${ }_{\text {cyt }}$ did, but showed higher association and dissociation rate constants $\left(\mathrm{k}_{\mathrm{a}}=(1.1 \pm\right.$ $0.3) \times 10^{6} \mathrm{M}^{-1} \mathrm{~s}^{-1}$ and $\left.\mathrm{k}_{\mathrm{d}}=(4.0 \pm 1.1) \times 10^{-3} \mathrm{~s}^{-1}\right)$ (Figure 1D).

Taken together, our data indicated that both $\mathrm{PLM}_{\mathrm{cyt}}$ and pSer68-PLM $\mathrm{cyt}_{\text {cyt }}$ bound strongly to $\mathrm{NCX}_{\text {cyt }}$, but the noninhibitory $\mathrm{PLM}_{\mathrm{cyt}}-\mathrm{NCX}_{\mathrm{cyt}}$ interaction exhibited higher association and dissociation rate constants (higher on/off rates).

\section{Identification of the Minimum pSer68-PLM Binding Sequence and of the $\mathrm{N}$-Terminus as Substitution Tolerant}

To develop a proteolytically stable NCX1 activator peptide, we used a previously designed high affinity PLM binding peptide (OPT: YHPYKEIEQLIELANYQVLS) that was derived from amino acids $301-320$ in NCX1 that contained most of the 
QKHPD motif (Figure 1A) (Wanichawan et al., 2016). OPT has previously been shown to bind to the flexible region that is found upstream of serine 68 in PLM $_{\text {cyt }}$ and to have a somewhat broader binding motif compared with that of the NCX1 region 301-320 (illustrated in Figure 2A, 41RCKFNQQQRTGEPDEEEGTFRSSIRR-63, in red) (Wanichawan et al., 2016). OPT and NCX1 thus bind PLM independently of the phosphorylation status of serine 68 .

To identify the minimal PLM binding sequence, we overlaid the biotinylated pSer68-PLM cyt $_{\text {t }}$ sequence (illustrated in Figure 1B, upper panel) onto $\mathrm{N}$ - or C-terminal truncations of OPT that was spotsynthesized on membranes. Immunoblotting with HRP-conjugated anti-biotin showed that OPT retained most of its pSer68-PLM cyt $_{1}$ binding capacity, although three or two amino acids were deleted at its $\mathrm{N}$ - (Figure 2B) or C-terminus (Figure 2C), respectively. We also performed $\mathrm{N}$ - and C-terminal truncations of OPT concomitantly (Figure 2D). Taken together, we identified the 16-amino acids sequence PYKEIEQLIELANYQV (mini-OPT) as the minimum sequence that was required to bind pSer68-PLM $\mathrm{Pyt}_{\mathrm{cy}}$.

To examine the substitution tolerance of this amino acid sequence, mini-OPT was analyzed by a two-dimensional peptide array, in which each amino acid (Figure 2E, sequence given above array) was systematically replaced with every possible other amino acid (Figure 2E, left of the array). When the membrane was overlaid with biotin-pSer68-PLM ${ }_{\text {cyt }}$ and HRPconjugated anti-biotin was immunodetected, it was observed that positions 1-5 (P1, Y2, K3, E4, and I5), 7 (Q7), 12 (A12) and 15 (Q15) were tolerant of amino acid substitutions, whereas position 6 (E6), 8-11 (L8, I9, E10 and L11), 13-14 (N13 and Y14) and 16 (V16) were less tolerant (Figure 2E, yellow columns). Some of the substitutions in positions $1-5,7,12$ and 15 appeared also to have a higher affinity for pSer68-PLM ${ }_{\text {cyt }}$ (Figure 2E, green circles) compared with the internal control peptides (Figure 2E, white circles), and were therefore tested in a second array. However, closer inspection revealed that these amino acid substitutions did not increase the pSer68-PLM binding further (Supplementary Figure S1A).

Conclusively, we identified PYKEIEQLIELANYQV (named mini-OPT) to hold the maximum pSer68-PLM cyt $_{\text {binding }}$ capacity and to be substitution-tolerant at the $\mathrm{N}$-terminus.

\section{Improvement of Peptide Stability and Retention of Capacity to Bind Phospholemman}

$\mathrm{N}$-methyl-amino acid substitutions have been shown to improve metabolic stability of peptides (Chatterjee et al., 2008; Ding et al., 2020). Therefore the N-terminal proline in the minimal pSer68PLM $_{\text {cyt }}$ binding sequence (mini-OPT) was substituted with an $\mathrm{N}$-methyl-proline (NMP). This novel synthetic peptide was named NOPT. To analyze the stability of the peptide, we employed human serum which is the first compartment to which the peptides would be exposed during intravenous administration. Both the NOPT and OPT peptides (Wanichawan et al., 2016) (illustrated in the upper panel of Figure 3A) were incubated in 30\% human serum and their degradation patterns were analyzed by mass spectrometry.
Whereas the half-life of OPT was very short $(0.86 \mathrm{~h})$, the halflife of the smaller NOPT peptide was found to be 17 times higher than this $(14.9 \mathrm{~h})$ (Figure 3A, lower panel; MS data in Supplementary Tables S1-S6).

To confirm that the NOPT retained the PLM and pSer68-PLM binding capacities, several binding analyses were performed. First, a pull down experiment was performed with biotinylated peptides (which are illustrated in Figure 3B) in rat left ventricle lysate. Immunoblotting with PLM antibodies showed that NOPT-biotin precipitated endogenous PLM, although the binding capacity appeared somewhat reduced compared with that of biotin-ahxOPT and the smaller biotin-ahx-mini-OPT (without the NMP substitution) (Figure 3C). Moreover, when peptides were used with a C-terminal biotin tag in an ELISA assay, it was confirmed that NOPT bound to pSer68-PLM nearly as well as the OPT and mini-OPT did (Figure 3D). Next, we analyzed the binding affinity of NOPT to pSer68-PLM $\mathrm{Cyt}_{\mathrm{c}}$ by SPR. A range of concentrations of NOPT was injected over immobilized biotin-ahx-pSer68-PLM ${ }_{\mathrm{cyt}}$ on a SA chip. Using the steady state affinity model, the dissociation equilibrium constant $\left(\mathrm{K}_{\mathrm{D}}\right)$ for the NOPT-pSer68-PLM $\mathrm{Cyt}_{\mathrm{c}}$ interaction was found to be $129 \mathrm{nM}$ (Figure 3E, the blank subtracted sensorgrams are shown in Supplementary Figure S1B). The dissociation rate $\left(k_{d}\right)$ and association rate constants $\left(k_{a}\right)$ were too fast to be determined. Despite its high on/off rates and lower binding affinity, excess NOPT reduced the biotin-ahx$\mathrm{PLM}_{\text {cyt }}-\mathrm{NCX} 1_{\text {cyt }}$ interaction with approximately $50 \%$ in an ELISA-based competition assay (Figure 3F). However, when applied to left ventricle lysate, NOPT was not able to outcompete the physical interaction between the two full length proteins (Figure 3G). This finding is in line with that NCX1 and PLM might be in larger protein complexes consisting of NCX1 dimers and higher order PLM oligomers (Beevers and Kukol, 2006; Bossuyt et al., 2006; Song et al., 2011).

Altogether, NOPT exhibited improved peptide stability, retained most of its PLM/pSer68-PLM binding capacities, and reduced the $\mathrm{PLM}_{\text {cyt }}-\mathrm{NCX1}_{\text {cyt }}$ interaction, but was not able to outcompete the physical interaction between the endogenous full length proteins.

\section{NOPT Increases NCX1 Activity in Adult Cardiomyocytes}

Initially and before we developed NOPT, we established that the OPT peptide did not have any effect on NKA activity in isolated adult rat cardiomyocytes (Figure 4A). Consistently, we found that presence of high concentrations $(100 \mu \mathrm{M})$ of OPT or the smaller proteolytically stable NOPT did not affect the endogenous PLM/pSer68-PLM-NKA interaction in left ventricular lysate (Figure 4B). These findings are in line with that NKA binds to the transmembrane domain of the PLM monomer (Shattock et al., 2015), and not the cytoplasmic part $\left(\mathrm{PLM}_{\mathrm{cyt}}\right.$ and pSer68-PLM $\left.\mathrm{Pyt}\right)$ of the PLM dimer as NCX1.

We further analyzed the effect of NOPT on endogenous NCX1 activity in adult mouse cardiomyocytes. NOPT was made cell permeable by the addition of a TAT tag to its C-terminus. Compared with a TAT-tagged, scrambled control peptide, NOPTTAT increased the activity of NCX1, as measured as the NCX1 rate constant, in adult cardiomyocytes that were isolated from both 

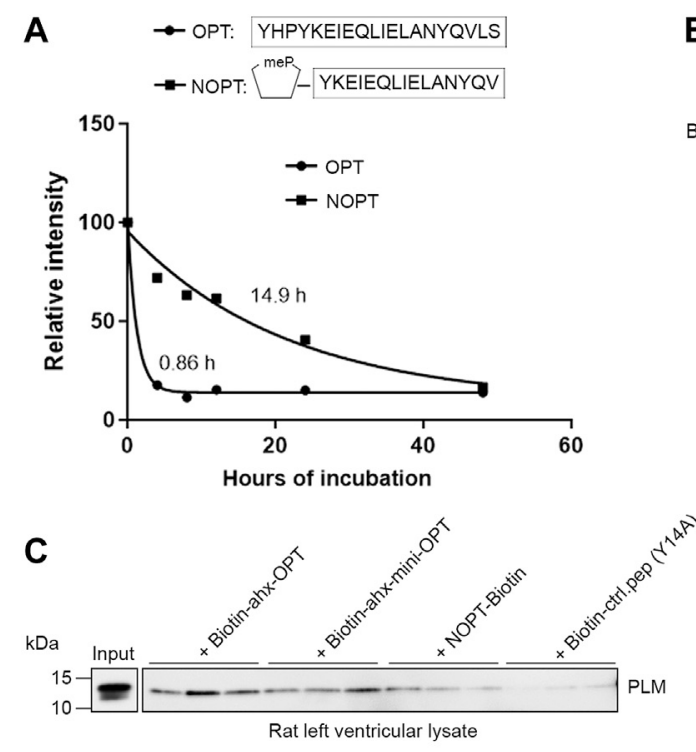

E NOPT binding to biotin-ahx-pSer68-PLM

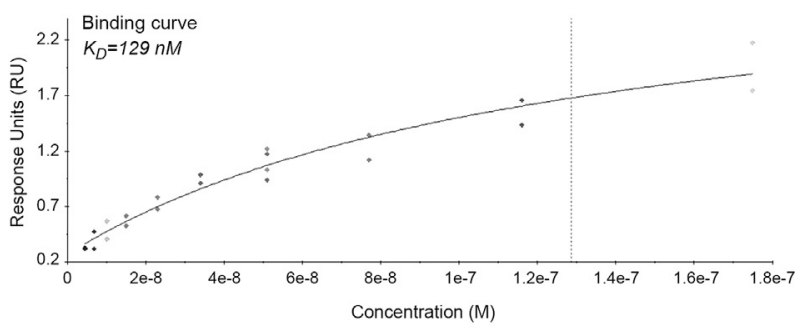

G

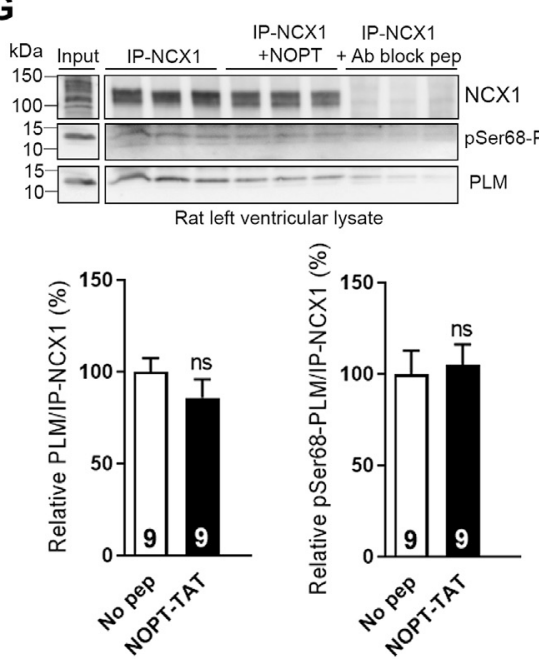

B

Biotin-ahx-OPT:

Biotin-ahx-mini-OPT:

NOPT-Biotin:

Biotin-ahx-E6G: (neg ctrl pep)

biotin -ahx- YHPYKEIEQLIELANYQVLS

biotin -ahx- PYKEIEQLIELANYQV

${ }^{\mathrm{meP}}$ - YKEIEQLIELANYQV - biotin

biotin -ahx- PYKEIGQLIELANYQV
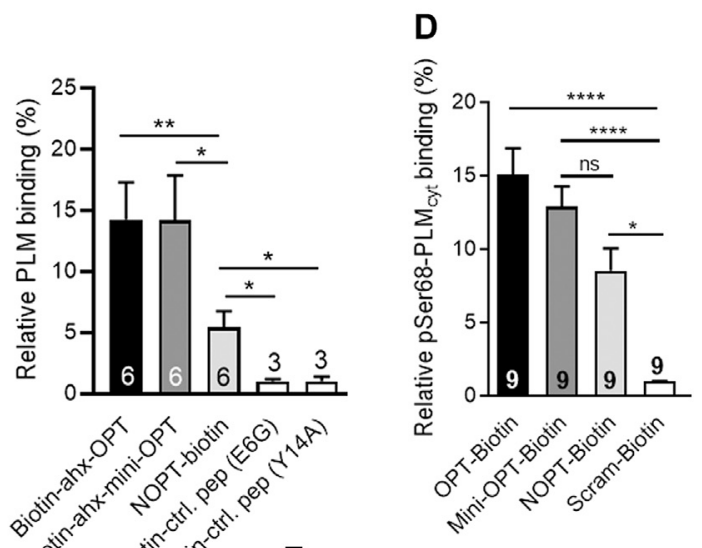

$\mathbf{F}$

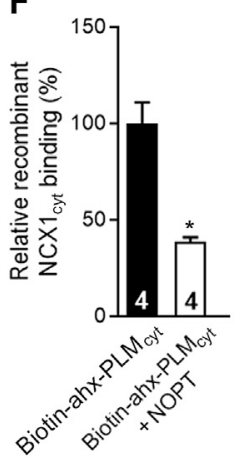

FIGURE 3 | Analyses of peptide stability in human serum and PLM binding capacity of NOPT. (A) Stability of OPT (black circles) ( $n=4$ ) and NOPT (black squares) $(n=3-7)$ in $30 \%$ human serum analyzed by mass spectrometry. The relative intensity of the full length peptide/total intensity is given vs. hours of incubation and set to $100 \%$ at 0 h. (B) Illustration of the peptides used in the pull down experiment in (C). (C) Pull down assay with biotin-ahx-OPT, biotin-ahx mini-OPT and NOPT-biotin in rat left ventricle lysate [peptides illustrated in (B)]. Except for NOPT, the biotin tag was added at the N-terminus of the peptides. An ahx-linker was included to avoid any potential steric hindrance. Endogenous PLM was detected with immunoblotting with PLM antibodies. ${ }^{*} p<0.05$, ${ }^{* *} p<0.01$, examined by Mann-Whitney test $(n=$ 3-6 rats, mean with SEM). Mini-OPT-E6G and mini-OPT-Y14A were used as negative control peptides (identified in Figure 2E, red circles). (D) Analyses of OPT-biotin, 
FIGURE 3 | mini-OPT-biotin and NOPT-biotin binding to pSer68-PLM (coated in the wells and without a biotin tag) in an ELISA-based assay. Binding was detected with a monoclonal anti-biotin-HRP conjugated antibody following incubation with an Ultra TMB solution. ${ }^{*} p<0.05$, ${ }^{\star \star * *} p<0.001$, examined by one-way ANOVA with Tukey's multiple comparison test ( $n=9$, mean with SEM). (E) Binding data of NOPT (4.5-175 nM) to biotin-ahx-pSer68-PLM model). The data are obtained from two SPR analyses, and the blank subtracted sensorgrams are shown in Supplementary Figure S1B. (F) Biotinylated-ahx-PLM cyt was incubated with or without excess NOPT (without any biotin tag) in wells coated with recombinant NCX $1_{\text {cyt }}$ protein. ${ }^{*} p<0.05$, examined by Mann-Whitney test $(n=4$, mean with SEM). (G) Immunoprecipitation of endogenous NCX1-PLM/pSer68-PLM from rat left ventricle lysate with or without the presence of NOPT. The precipitates were analyzed by immunoblotting with specific antibodies against NCX1, PLM and pSer68-PLM. An NCX1 antibody blocking peptide (Ab block pep) was used as negative control. Ns, examined with unpaired $t$-test ( $n=9$, mean with SEM). Notably, densitometry analyses of the immunoblots indicated that five times more PLM coprecipitated with NCX1 (lane 1-3) compared with negative control (lane 7-9) (Supplementary Figure S1C).

SHAM-operated (Figure 4C, approximately 40\%) and aorta banded HF mice (Figure 4D, approximately 60\%). NOPT-TAT did not change the $\mathrm{Ca}^{2+}$ transient amplitude or sarcoplasmic reticulum (SR) $\mathrm{Ca}^{2+}$ load in either SHAM (Figures 4E,G) or HF cardiomyocytes (Figures 4F,H). Representative tracings for NCX1 activity in SHAM and HF cardiomyocytes treated with the scrambled control peptide or NOPT-TAT are shown in Figures 4I-L.

Altogether, cell-permeable NOPT was found to increase endogenous NCX1 activity in adult cardiomyocytes that were isolated from both SHAM-operated and aorta banded HF mice. This finding suggests that NOPT is able to disrupt the inhibitory pSer68-PLM-NCX1 interaction.

\section{DISCUSSION}

In the present study, we aimed to analyze the binding affinities and kinetics of the possible PLM-NCX1 and pSer68-PLM-NCX1 interactions by SPR, and to develop a proteolytically stable NCX1 activator peptide for future in vivo studies. The cytoplasmic parts of PLM and pSer68-PLM interacted strongly with the cytoplasmic loop of NCX1, and showed similar $K_{D}$ values of $4.1 \pm 1.0 \mathrm{nM}$ and $4.3 \pm 1.9 \mathrm{nM}$, respectively. Although the binding affinities of the two interactions were similar, the non-inhibitory $\mathrm{PLM}_{\text {cyt }}-\mathrm{NCX}_{\text {cyt }}$ interaction had higher association and dissociation rate constants (higher on/off rates) compared with those of pSer68-PLM $\mathrm{cyt}^{-\mathrm{NCX}} 1_{\mathrm{cyt}}$. These data strongly support previous findings that PLM and pSer68-PLM are direct NCX1 binding partners (Zhang et al., 2011; Wanichawan et al., 2016). However, an absence of interaction between PLM and NCX1 has also been reported (Bossuyt et al., 2006). In this latter study, the FRET reporter was cloned into the recently identified PLM binding region of NCX1 (Wanichawan et al., 2016), which might be a possible explanation for the non-detectable PLMNCX1 interaction. False negative findings in immunoprecipitation experiments might also result if the PLM antibody epitope overlaps with the NCX1 binding site in PLM (41-RCKFNQQQRTGEPDEEEGTF-60) (Wanichawan et al., 2016). Such an antibody will only precipitate PLM without any NCX1 bound to it. Since the cytoplasmic part of PLM consists of only 36 amino acids, this likely applies to several PLM antibodies.

To develop a proteolytically stable NCX1 activator peptide, we used a previously optimized PLM binding peptide (OPT, 20mer), which had been shown to exhibit an 8 -fold increase in pSer68-PLM binding affinity and to reverse PLM (S68D) inhibition of exogenously expressed NCX1 in HEK293 cells (Wanichawan et al., 2016). The final novel NOPT peptide (16mer), which was the minimum pSer68-PLM binding sequence of OPT substituted with an N-methyl proline; exhibited a half-life of $14.9 \mathrm{~h}$ in $30 \%$ human serum, precipitated endogenous PLM from left ventricle lysate and was found to bind directly to pSer68$\mathrm{PLM}_{\text {cyt }}$. Although NOPT exhibited a lower binding affinity than NCX1 to pSer68-PLM, excess NOPT was able to reduce the $\mathrm{PLM}_{\text {cyt }}-\mathrm{NCX}_{\text {cyt }}$ interaction, suggesting that NOPT upon binding might induce a conformational change in PLM (or in its oligomerization state) that makes it less competent to bind NCX1. Compound induced conformational changes have also been reported for other proteins (Smith and Gestwicki, 2012). Notably, NOPT was not able to disrupt the physical interaction between the endogenous full length proteins, which is in line with previous studies reporting that NCX1 and PLM molecules probably are embedded in larger PLM-NCX1 protein complexes, consisting of NCX1 dimers (Ren et al., 2008; John et al., 2011) and higher order PLM oligomers (Beevers and Kukol, 2006; Bossuyt et al., 2006; Song et al., 2011). Identification of two PLM binding sites in the NCX1 monomer adds even more complexity to the PLM-NCX1 interaction (Zhang et al., 2011; Wanichawan et al., 2016). Importantly, cell-permeable NOPTTAT increased the activity of NCX1 in adult cardiomyocytes that were isolated from both SHAM-operated and aorta banded HF mice, strongly suggesting that NOPT disrupts the functional inhibitory pSer68-PLM-NCX1 interaction (illustrated in Figure 5).

Since insulin's first use as therapy in the 1920s, more than 150 peptides have been studied clinically and over 60 peptides have been approved for clinical use (Lau and Dunn, 2018). Most of these peptides have been developed for use within the fields of metabolic disease, oncology and cardiovascular disease, which are of great interest to the pharmaceutical industry. Several peptides are so-called replacement therapies that supplement peptide hormones in cases in which endogenous levels are inadequate, but peptides that disrupt protein-protein interactions have also entered the clinic (Stupp et al., 2014). Although most of the targets are extracellular proteins, such as G-protein-coupled and natriuretic peptide receptors, some are also directed against intracellular proteins and are delivered into the cell though application of cell-penetration strategies (Lau and Dunn, 2018).

Many cardiac proteins, such as NCX1 and PLM, play key roles in cardiovascular disease, making them attractive drug targets. Peptides that are derived from the binding surfaces of these proteins are potential drug candidates because they are easily 


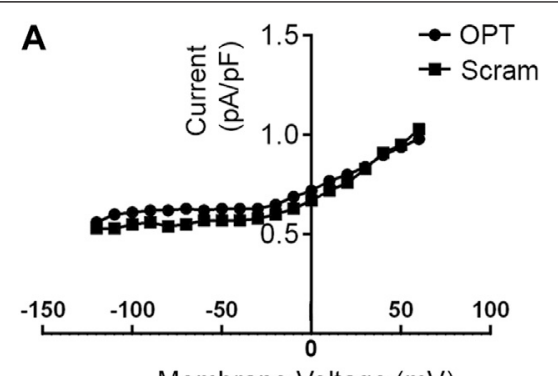

Membrane Voltage (mV)

C

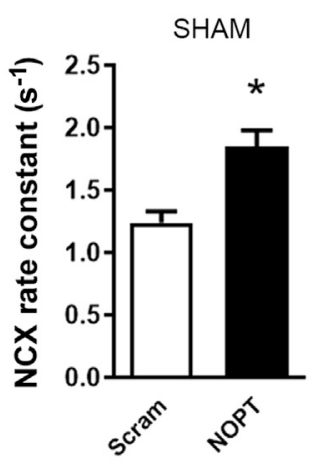

G

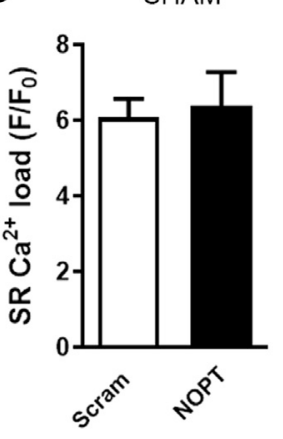

D

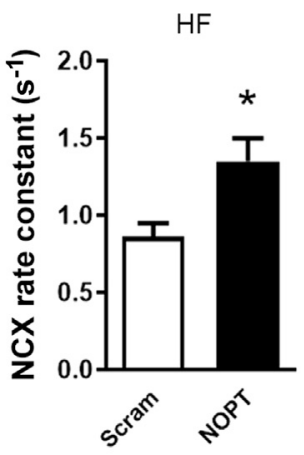

B

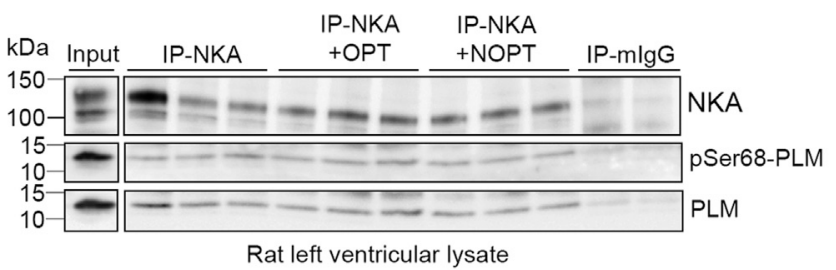

E

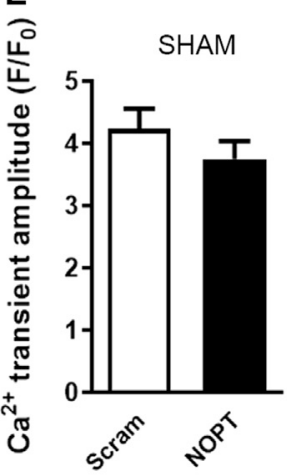

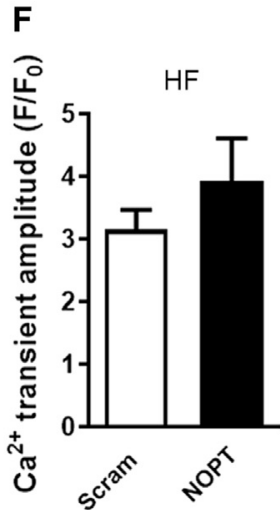

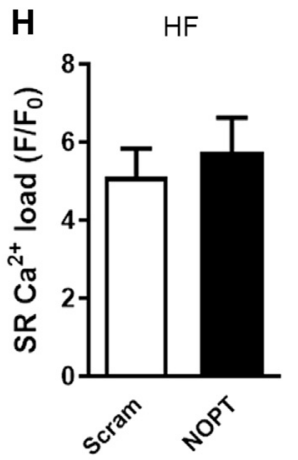

I Scram in SHAM

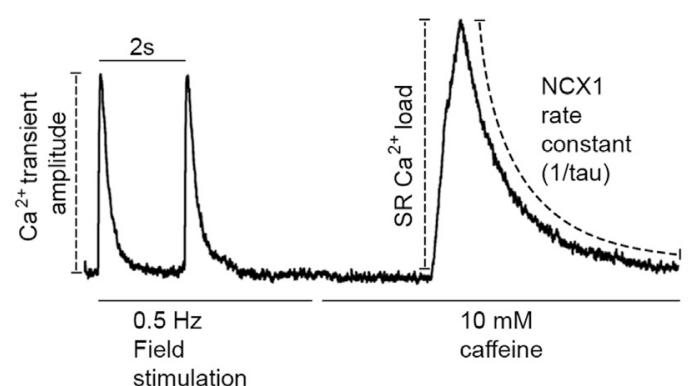

J NOPT in SHAM

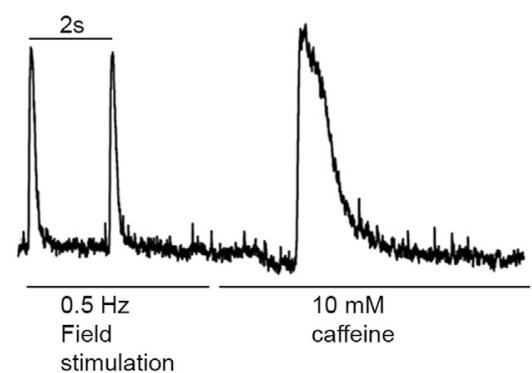

K Scram in HF

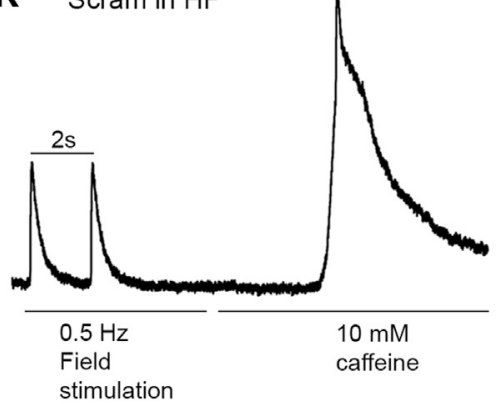

L NOPT in HF

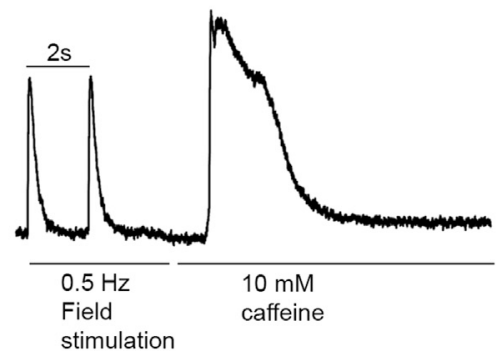

FIGURE 4 | NOPT increases NCX-mediated $\mathrm{Ca}^{2+}$ extrusion in cardiomyocytes isolated from SHAM-operated and aorta banded HF mice. (A) No effect of the 20mer original OPT peptide (Wanichawan et al., 2016) on NKA current was confirmed in adult rat cardiomyocytes. A scrambled control peptide was used as control ( $n=6$ cells from three rats). (B) Immunoprecipitation of NKA-PLM/pSer68-PLM from rat left ventricle lysate with or without in presence of OPT or NOPT (100 $\mu M$ ). The precipitates were analyzed by immunoblotting with specific antibodies against NKA, PLM and pSer68-PLM. Non relevant mouse lgG (mlgG) was used as negative control $(n=3)$. Average NCX rate constant measured in field stimulated (C) SHAM and (D) HF cardiomyocytes that were treated with NOPT-TAT or a scrambled control peptide. Average $\mathrm{Ca}^{2+}$ transient amplitude measured in field-stimulated (E) SHAM and (F) HF cardiomyocytes that were treated with NOPT-TAT or a scrambled control 
FIGURE 4 | peptide. Average SR Ca ${ }^{2+}$ load from field stimulated (G) SHAM and (H) HF cardiomyocytes treated with NOPT-TAT or a scrambled control peptide. Totals of 10-13 cells from three mice were used in (C, E, G), and 6-7 cells from three mice were used in (D, F, H). * $p<0.05$ vs scrambled control peptide examined with unpaired Student's t-test (mean with SEM). Representative tracings of NCX1 activity in SHAM cardiomyocytes treated with (I) scrambled peptide or (J) NOPT-TAT. Representative tracings of NCX1 activity in HF cardiomyocytes treated with (K) scrambled peptide or (L) NOPT-TAT. All representative tracings (I-L) are normalized, and stimulation to evoke regular or caffeine induced $\mathrm{Ca}^{2+}$ transients is indicated for each cell. Illustration of analyses performed are shown in Panel (I).

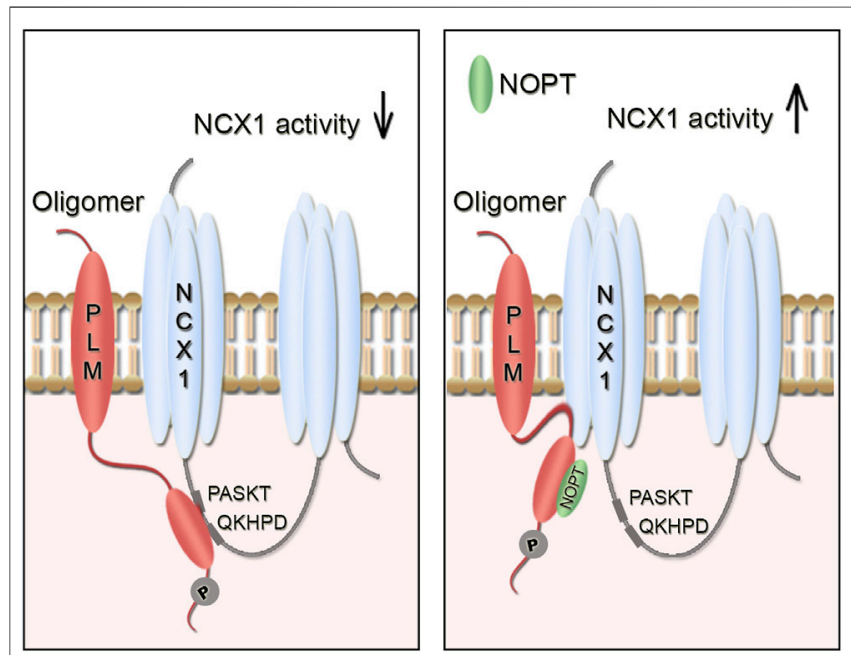

FIGURE 5 | Illustration of the inhibitory pSer68-PLM-NCX1 interaction in heart and relief of its inhibition by NOPT. (A) Without NOPT, the pSer68-PLM dimer binds to the cytoplasmic part of NCX1 and inhibits NCX1 activity. (B) Binding of NOPT to PLM disrupts the inhibitory pSer68-PLM-NCX1

interaction, leading to increased NCX1 activation. NOPT does not disrupt the physical interaction between the endogenous full length proteins, which is in line with that NCX1 and PLM might be embedded in larger PLM-NCX1 protein complexes, consisting of NCX1 dimers (Ren et al., 2008; John et al., 2011) and PLM oligomers (Beevers and Kukol, 2006; Bossuyt et al., 2006; Song et al., 2011). It is also possible that two PLM molecules (dimer) bind to the two PASKT- and QKHPD-motifs in the NCX1 monomer.

synthesized and show high specificity and low toxicity. The binding affinities of such peptides to specific partners can also be optimized easily by amino acid substitutions (Carlson et al., 2006; Gold et al., 2006; Wanichawan et al., 2016). These peptides show close structural similarity to endogenous proteins and peptides, and therefore offer relatively low immunogenicity risks compared with other therapeutics (Ding et al., 2020). However, in general native peptides have short plasma halflives due to the high concentrations of proteases in the human serum and rapid renal clearance and hepatic metabolism (Zaman et al., 2019). To overcome the problem with proteolytic degradation, incorporation of artificial amino acids, such as $\mathrm{N}$-methyl amino acids, has been shown to improve peptide stability (Chatterjee et al., 2008; Ding et al., 2020). Consistently, it was found in this study that replacement of the N-terminal proline with an N-methyl-proline increased the stability of NOPT 17 -fold in vitro (this study) compared with the OPT peptide (Wanichawan et al., 2016). This chemical modification affected only slightly the pSer68-PLM binding capacity of NOPT. Since the N-terminus of the peptide was identified to be the most substitution tolerant part of the molecule, we avoided any further chemical modifications either internally or at the C-terminus. Peptides can also be made more stable trough use of other strategies such as peptide cyclization (Ding et al., 2020) or to conjugate the peptide of interest to polyethylene glycol (PEG), lipids and proteins such as Fc fragments (Lau and Dunn, 2018). Modification of the peptide surface charge or increasing its hydrodynamic radius by conjugation to e.g. PEG or an unstructured polypeptide polymer, are strategies that can be used to reduce the renal clearance rate (Zaman et al., 2019). Ways to reduce renal clearance and hepatic metabolism of NOPT has to be determined in future studies.

The effect of NOPT in vivo remains an area for future investigation. We suggest that NOPT be delivered into animals continuously by use of osmotic mini-pumps. This strategy has been used recently to show the cardioprotection effect of a non-modified linear peptide with a half-life of $1.5 \mathrm{~h}$ (Altara et al., 2020). Increased NCX1 activity might not be beneficial in HF with reduced ejection fraction (HFrEF) where contractility is depressed. However, enhanced NCX1 activity and $\mathrm{Ca}^{2+}$ extrusion might be beneficial in subgroups of patients with $\mathrm{HF}$ with preserved ejection fraction (HFpEF), in which NCX1 activity has been reduced because of, e.g., increased and dominating $\mathrm{Na}^{+}$levels (Eisner et al., 2020), and in HF that involves increased levels of pSer68-PLM (Bossuyt et al., 2005; Hafver et al., 2016). A study has supported the suggestion that increased NCX1 activity in HFpEF might have a beneficial effect. This study, of ventricular strips from failing human hearts, showed that the greater the expression of NCX1, the better was the diastolic function (Hasenfuss et al., 1999). Beneficial effects of increased NCX1 expression and activity have also been reported in several animal HF models. The induction of NCX1 overexpression in mice whose hearts had undergone pathological remodeling due to pressure overload was shown to reverse NCX1 activity to basal level and to prevent chamber dilatation with cardiac dysfunction (Ujihara et al., 2016). The cardiomyocytes that overexpressed NCX1 showed improved contractility, T-tubule integrity, and synchrony of the $\mathrm{SR} \mathrm{Ca}^{2+}$ release and $\mathrm{Ca}^{2+}$ handling during EC coupling. Overexpression of NCX1 has also been shown to rescue postinfarction rat myocytes from contractile dysfunction (Zhang et al., 2002) and to attenuate myocardial dysfunction after infarction (Min et al., 2002). It is not clear whether the beneficial effects that were observed in these animal studies were due to the increased NCX1 protein levels, NCX1 activity or perhaps a combination of both; however, administration of NOPT into the animals could address this question in the future.

Finally, NOPT might also offer therapeutic potential in the brain, since PLM also interacts with NCX1 in this tissue (Wanichawan 
et al., 2016). The NCX protein family, which consists of the NCX1, NCX2 and NCX3 isoforms, has been shown to play a pivotal role in the maintenance of intracellular $\mathrm{Na}^{+}$and $\mathrm{Ca}^{2+}$ homeostasis in the brain, and to have a protective role in neurodegenerative disorders, such as Alzheimer's disease (Pannaccione et al., 2020) and brain ischemia (Molinaro et al., 2013). Moreover, overexpression of NCX1 and NCX3 has been shown to protect neurons in ischemic preconditioning (Pignataro et al., 2012).

Conclusively, in the present work described here, we identified strong pSer68-PLM/PLM-NCX1 interactions and designed a proteolytically stable NCX1 activator peptide (NOPT) for future in vivo studies. NOPT was found to precipitate endogenous PLM, bind directly to pSer68-PLM and reduce the PLM $\mathrm{Cyt}_{\text {cyt }} \mathrm{NCX}_{\text {cyt }}$ interaction and increase NCX1 activity in adult cardiomyocytes that were isolated from both SHAM-operated and aorta banded HF mice. NOPT might be a valuable tool to analyze the role of direct NCX1 activation in vivo, and to discover whether increased NCX1 activation is beneficial in different types of HF.

\section{DATA AVAILABILITY STATEMENT}

All data required to evaluate the work are included in the article, and Supplementary Material. The mass spectrometry proteomics data have been deposited to the ProteomeXchange Consortium via the PRIDE (Perez-Riverol et al., 2019) partner repository with the dataset identifier PXD022797.

\section{ETHICS STATEMENT}

The animal study was reviewed and approved by the Norwegian National Animal Research Committee.

\section{AUTHOR CONTRIBUTIONS}

PW and CC: conceptualization, investigation, methodology, visualization, writing the original draft and funding acquisition. JS:

\section{REFERENCES}

Ackers-Johnson, M., Li, P. Y., Holmes, A. P., O’Brien, S.-M., Pavlovic, D., and Foo, R. S. (2016). A Simplified, Langendorff-free Method for Concomitant Isolation of Viable Cardiac Myocytes and Nonmyocytes from the Adult Mouse Heart. Circ. Res. 119, 909-920. doi:10.1161/circresaha.116.309202

Ahlers, B. A., Zhang, X.-Q., Moorman, J. R., Rothblum, L. I., Carl, L. L., Song, J., et al. (2005). Identification of an Endogenous Inhibitor of the Cardiac $\mathrm{Na}+/$ Ca2+ Exchanger, Phospholemman. J. Biol. Chem. 280, 19875-19882. doi:10. 1074/jbc.m414703200

Altara, R., da Silva, G. J. J., Frisk, M., Spelta, F., Zouein, F. A., Louch, W. E., et al. (2020). Cardioprotective Effects of the Novel Compound Vastiras in a Preclinical Model of End-Organ Damage. Hypertension 75, 1195-1204. doi:10.1161/hypertensionaha.120.14704

Barman, P., Choisy, S. C. M., Hancox, J. C., and James, A. F. (2011). $\beta$-Adrenoceptor/PKA-stimulation, $\mathrm{Na}+\mathrm{Ca} 2+$ Exchange and PKA-Activated Cl- Currents in Rabbit Cardiomyocytes: A Conundrum. Cell Calcium 49, 233-239. doi:10.1016/j.ceca.2011.02.006

Beevers, A. J., and Kukol, A. (2006). Secondary Structure, Orientation, and Oligomerization of Phospholemman, a Cardiac Transmembrane Protein. Protein Sci. 15, 1127-1132. doi:10.1110/ps.051899406 investigation, methodology, visualization, and review and editing of the original draft. ML, TS, MS, TN, and JA: investigation, methodology, and review and editing of the original draft. IS and OS: methodology, review and editing of the original draft, and funding acquisition. All authors read and approved the manuscript.

\section{FUNDING}

This work was supported by The Research Council of Norway Olav Raagholt og Gerd Meidel Raagholts stiftelse for forskning (http://www.raagholtstiftelsen.no/), Stiftelsen Kristian Gerhard Jebsen, Anders Jahre's Fund for the Promotion of Science and the South-Eastern Norway Regional Health Authority. Proteomics Core Facility was supported by the Core Facilities Program of the South-Eastern Norway Regional Health Authority. The Proteomics core facility is also a member of the National Network of Advanced Proteomics Infrastructure (NAPI), which is funded by the Research Council of Norway INFRASTRUKTUR-program (project number: 295910).

\section{SUPPLEMENTARY MATERIAL}

The Supplementary Material for this article can be found online at: https://www.frontiersin.org/articles/10.3389/fphar.2021.638646/ full\#supplementary-material

Supplementary Figure 1(A) | The 17 mini-OPT derivatives were analyzed for pSer68-PLM binding in a second peptide array and immunodetected with antibiotin-HRP (lower panel). The relative pSer68-PLM binding was quantified by densitometry analysis and normalized to the average of OPT which was set to 1 (upper panel). ${ }^{\star} p<0.05,{ }^{\star \star} p<0.01,{ }^{\star \star \star} p<0.001,{ }^{\sharp} p<0.05$ (mini-OPT versus $15 \mathrm{~L}$ substitution), examined by ordinary one-way ANOVA with Dunnett's multiple comparison test ( $n=6$, mean with SEM). (B) Blank subtracted sensorgrams of

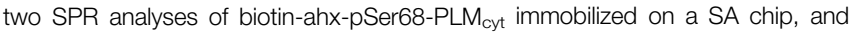
NOPT-TAT injected at a range of concentrations (4.5-175 nM) over the chip. (C) Densitometry analyses of the amount of PLM that co-precipitated with NCX1 compared with negative control (immunoblot is shown in Figure $\mathbf{3 G}$ ). ${ }^{\star \star} p<0.01$, examined by unpaired t-test ( $n=3$, mean with SEM).

Blaustein, M. P., and Lederer, W. J. (1999). Sodium/calcium Exchange: its Physiological Implications. Physiol. Rev. 79, 763-854. doi:10.1152/physrev. 1999.79.3.763

Bossuyt, J., Ai, X., Moorman, J. R., Pogwizd, S. M., and Bers, D. M. (2005). Expression and Phosphorylation of the Na-Pump Regulatory Subunit Phospholemman in Heart Failure. Circ. Res. 97, 558-565. doi:10.1161/01.res. 0000181172.27931.c3

Bossuyt, J., Despa, S., Martin, J. L., and Bers, D. M. (2006). Phospholemman Phosphorylation Alters its Fluorescence Resonance Energy Transfer with the Na/K-ATPase Pump. J. Biol. Chem. 281, 32765-32773. doi:10.1074/jbc. m606254200

Carlson, C. R., Lygren, B., Berge, T., Hoshi, N., Wong, W., Taskén, K., et al. (2006). Delineation of Type I Protein Kinase A-Selective Signaling Events Using an RI Anchoring Disruptor. J. Biol. Chem. 281, 21535-21545. doi:10.1074/jbc. m603223200

Chatterjee, J., Gilon, C., Hoffman, A., and Kessler, H. (2008). N-methylation of Peptides: a New Perspective in Medicinal Chemistry. Acc. Chem. Res. 41, 1331-1342. doi:10.1021/ar8000603

Cheung, J. Y., Zhang, X.-Q., Song, J., Gao, E., Chan, T. O., Rabinowitz, J. E., et al. (2013). Coordinated Regulation of Cardiac $\mathrm{Na}+\mathrm{Ca} 2+$ Exchanger and $\mathrm{Na}+\mathrm{K}+-$ ATPase by Phospholemman (FXYD1). Adv. Exp. Med. Biol. 961, 175-190. doi:10.1007/978-1-4614-4756-6_15 
Cox, J., and Mann, M. (2008). MaxQuant Enables High Peptide Identification Rates, Individualized p.p.b.-range Mass Accuracies and Proteome-wide Protein Quantification. Nat. Biotechnol. 26, 1367-1372. doi:10.1038/nbt. 1511

Despa, S., and Bers, D. M. (2003). Na/K Pump Current and [Na]i in Rabbit Ventricular Myocytes: Local [Na]i Depletion and Na Buffering. Biophysical J. 84, 4157-4166. doi:10.1016/s0006-3495(03)75140-6

Díaz, M. E., Trafford, A. W., O’Neill, S. C., and Eisner, D. A. (1997). Measurement of Sarcoplasmic Reticulum Ca2+ Content and Sarcolemmal Ca2+ Fluxes in Isolated Rat Ventricular Myocytes during Spontaneous Ca2+ Release. J. Physiol. 501 (Pt 1), 3-16. doi:10.1111/j.1469-7793.1997.003bo.x

Ding, Y., Ting, J. P., Liu, J., Al-Azzam, S., Pandya, P., and Afshar, S. (2020). Impact of Non-proteinogenic Amino Acids in the Discovery and Development of Peptide Therapeutics. Amino Acids 52, 1207-1226. doi:10.1007/s00726-02002890-9

Eisner, D. A., Caldwell, J. L., Trafford, A. W., and Hutchings, D. C. (2020). The Control of Diastolic Calcium in the Heart. Circ. Res. 126, 395-412. doi:10.1161/ circresaha.119.315891

Frank, R. (1992). Spot-synthesis: an Easy Technique for the Positionally Addressable, Parallel Chemical Synthesis on a Membrane Support. Tetrahedron 48, 9217-9232. doi:10.1016/s0040-4020(01)85612-x

Frank, R. (2002). The SPOT-Synthesis Technique. J. Immunological Methods 267, 13-26. doi:10.1016/s0022-1759(02)00137-0

Fuller, W., Howie, J., McLatchie, L. M., Weber, R. J., Hastie, C. J., Burness, K., et al. (2009). FXYD1 Phosphorylation In Vitro and in Adult Rat Cardiac Myocytes: Threonine 69 Is a Novel Substrate for Protein Kinase C. Am. J. Physiology-Cell Physiol. 296, C1346-C1355. doi:10.1152/ajpcell.00523.2008

Ginsburg, K. S., and Bers, D. M. (2005). Isoproterenol Does Not Enhance Cadependent $\mathrm{Na} / \mathrm{Ca}$ Exchange Current in Intact Rabbit Ventricular Myocytes. J. Mol. Cell Cardiol. 39, 972-981. doi:10.1016/j.yjmcc.2005.09.005

Gök, C., Plain, F., Robertson, A. D., Howie, J., Baillie, G. S., Fraser, N. J., et al. (2020). Dynamic Palmitoylation of the Sodium-Calcium Exchanger Modulates its Structure, Affinity for Lipid-Ordered Domains, and Inhibition by XIP. Cel. Rep. 31, 107697. doi:10.1016/j.celrep.2020.107697

Gold, M. G., Lygren, B., Dokurno, P., Hoshi, N., McConnachie, G., Taskén, K., et al. (2006). Molecular Basis of AKAP Specificity for PKA Regulatory Subunits. Mol. Cel. 24, 383-395. doi:10.1016/j.molcel.2006.09.006

Hafver, T. L., Hodne, K., Wanichawan, P., Aronsen, J. M., Dalhus, B., Lunde, P. K., et al. (2016). Protein Phosphatase 1c Associated with the Cardiac Sodium Calcium Exchanger 1 Regulates its Activity by Dephosphorylating Serine 68phosphorylated Phospholemman. J. Biol. Chem. 291, 4561-4579. doi:10.1074/ jbc.m115.677898

Hasenfuss, G., Schillinger, W., Lehnart, S. E., Preuss, M., Pieske, B., Maier, L. S., et al. (1999). Relationship between Na+-Ca2+-Exchanger Protein Levels and Diastolic Function of Failing Human Myocardium. Circulation 99, 641-648. doi:10.1161/01.cir.99.5.641

He, Z., Feng, S., Tong, Q., Hilgemann, D. W., and Philipson, K. D. (2000). Interaction of PIP2 with the XIP Region of the Cardiac Na/Ca Exchanger. Am. J. Physiology-Cell Physiol. 278, C661-C666. doi:10.1152/ajpcell.2000.278.4. c661

Iwamoto, T., Pan, Y., Wakabayashi, S., Imagawa, T., Yamanaka, H. I., and Shigekawa, M. (1996). Phosphorylation-dependent Regulation of Cardiac $\mathrm{Na}+\mathrm{Ca} 2+$ Exchanger via Protein Kinase C. J. Biol. Chem. 271, 13609-13615. doi:10.1074/jbc.271.23.13609

Iwamoto, T., Wakabayashi, S., and Shigekawa, M. (1995). Growth Factor-Induced Phosphorylation and Activation of Aortic Smooth Muscle $\mathrm{Na}+1$ Ca2+Exchanger. J. Biol. Chem. 270, 8996-9001. doi:10.1074/jbc.270.15.8996

John, S. A., Ribalet, B., Weiss, J. N., Philipson, K. D., and Ottolia, M. (2011). Ca2+dependent Structural Rearrangements within Na+-Ca2+ Exchanger Dimers. Proc. Natl. Acad. Sci. 108, 1699-1704. doi:10.1073/pnas.1016114108

Lau, J. L., and Dunn, M. K. (2018). Therapeutic Peptides: Historical Perspectives, Current Development Trends, and Future Directions. Bioorg. Med. Chem. 26, 2700-2707. doi:10.1016/j.bmc.2017.06.052

Lin, X., Jo, H., Sakakibara, Y., Tambara, K., Kim, B., Komeda, M., et al. (2006). $\beta$-Adrenergic Stimulation Does Not Activate $\mathrm{Na}+/ \mathrm{Ca} 2+$ Exchange Current in guinea Pig, Mouse, and Rat Ventricular Myocytes. Am. J. Physiology-Cell Physiol. 290, C601-C608. doi:10.1152/ajpcell.00452.2005
Lines, G. T., Sande, J. B., Louch, W. E., Mørk, H. K., Grøttum, P., and Sejersted, O. M. (2006). Contribution of the $\mathrm{Na}+/ \mathrm{Ca} 2+$ Exchanger to Rapid Ca2+ Release in Cardiomyocytes. Biophysical J. 91, 779-792. doi:10.1529/biophysj.105.072447

Maack, C., Ganesan, A., Sidor, A., and O'Rourke, B. (2005). Cardiac SodiumCalcium Exchanger Is Regulated by Allosteric Calcium and Exchanger Inhibitory Peptide at Distinct Sites. Circ. Res. 96, 91-99. doi:10.1161/01.res. 0000151334.48676.68

Matsuoka, S., Nicoll, D. A., He, Z., and Philipson, K. D. (1997). Regulation of the Cardiac Na+-Ca2+ Exchanger by the Endogenous XIP Region. J. Gen. Physiol. 109, 273-286. doi:10.1085/jgp.109.2.273

Melleby, A. O., Romaine, A., Aronsen, J. M., Veras, I., Zhang, L., Sjaastad, I., et al. (2018). A Novel Method for High Precision Aortic Constriction that Allows for Generation of Specific Cardiac Phenotypes in Mice. Cardiovasc. Res. 114, 1680-1690. doi:10.1093/cvr/cry141

Min, J.-Y., Sullivan, M. F., Yan, X., Feng, X., Chu, V., Wang, J.-F., et al. (2002). Overexpression of $\mathrm{Na}+/ \mathrm{Ca} 2+$ Exchanger Gene Attenuates Postinfarction Myocardial Dysfunction. Am. J. Physiology-Heart Circulatory Physiol. 283, H2466-H2471. doi:10.1152/ajpheart.01062.2001

Molinaro, P., Cataldi, M., Cuomo, O., Viggiano, D., Pignataro, G., Sirabella, R., et al. (2013). Genetically Modified Mice as a Strategy to Unravel the Role Played by the $\mathrm{Na}+/ \mathrm{Ca} 2+$ Exchanger in Brain Ischemia and in Spatial Learning and Memory Deficits. Adv. Exp. Med. Biol. 961, 213-222. doi:10.1007/978-1-4614-4756-6_18

Pannaccione, A., Piccialli, I., Secondo, A., Ciccone, R., Molinaro, P., Boscia, F., et al. (2020). The $\mathrm{Na}+/ \mathrm{Ca} 2+$ exchanger in Alzheimer's Disease. Cell Calcium 87, 102190. doi:10.1016/j.ceca.2020.102190

Perez-Riverol, Y., Csordas, A., Bai, J., Bernal-Llinares, M., Hewapathirana, S. Kundu, D. J., et al. (2019). The PRIDE Database and Related Tools and Resources in 2019: Improving Support for Quantification Data. Nucleic Acids Res. 47, D442-d450. doi:10.1093/nar/gky1106

Pignataro, G., Boscia, F., Esposito, E., Sirabella, R., Cuomo, O., Vinciguerra, A., et al. (2012). NCX1 and NCX3: Two New Effectors of Delayed Preconditioning in Brain Ischemia. Neurobiol. Dis. 45, 616-623. doi:10.1016/j.nbd.2011.10.007

Ren, X., Nicoll, D. A., Galang, G., and Philipson, K. D. (2008). Intermolecular Cross-Linking of $\mathrm{Na}+-\mathrm{Ca} 2+$ Exchanger Proteins: Evidence for Dimer Formation $\dagger$. Biochemistry 47, 6081-6087. doi:10.1021/bi800177t

Ruknudin, A., He, S., Lederer, W. J., and Schulze, D. H. (2000). Functional Differences between Cardiac and Renal Isoforms of the Rat Na + -Ca 2+ Exchanger NCX1 Expressed in Xenopus Oocytes. J. Physiol. 529, 599-610. doi:10.1111/j.1469-7793.2000.00599.x

Shattock, M. J., Ottolia, M., Bers, D. M., Blaustein, M. P., Boguslavskyi, A., Bossuyt, J., et al. (2015). $\mathrm{Na}+/ \mathrm{Ca} 2+$ exchange and $\mathrm{Na}+/ \mathrm{K}+$-ATPase in the Heart. J. Physiol. 593, 1361-1382. doi:10.1113/jphysiol.2014.282319

Smith, M. C., and Gestwicki, J. E. (2012). Features of Protein-Protein Interactions that Translate into Potent Inhibitors: Topology, Surface Area and Affinity. Expert Rev. Mol. Med. 14, e16. doi:10.1017/erm.2012.10

Song, Q., Pallikkuth, S., Bossuyt, J., Bers, D. M., and Robia, S. L. (2011). Phosphomimetic Mutations Enhance Oligomerization of Phospholemman and Modulate its Interaction with the Na/K-ATPase. J. Biol. Chem. 286, 9120-9126. doi:10.1074/jbc.m110.198036

Stupp, R., Hegi, M. E., Gorlia, T., Erridge, S. C., Perry, J., Hong, Y.-K., et al. (2014). Cilengitide Combined with Standard Treatment for Patients with Newly Diagnosed Glioblastoma with Methylated MGMT Promoter (CENTRIC EORTC 26071-22072 Study): a Multicentre, Randomised, Open-Label, Phase 3 Trial. Lancet Oncol. 15, 1100-1108. doi:10.1016/s1470-2045(14) 70379-1

Ujihara, Y., Iwasaki, K., Takatsu, S., Hashimoto, K., Naruse, K., Mohri, S., et al. (2016). Induced NCX1 Overexpression Attenuates Pressure Overload-Induced Pathological Cardiac Remodelling. Cardiovasc. Res. 111, 348-361. doi:10.1093/cvr/cvw113

Walaas, S. I., Czernik, A. J., Olstad, O. K., Sletten, K., and Walaas, O. (1994). Protein Kinase C and Cyclic AMP-dependent Protein Kinase Phosphorylate Phospholemman, an Insulin and Adrenaline-Regulated Membrane Phosphoprotein, at Specific Sites in the Carboxy Terminal Domain. Biochem. J. 304 (Pt 2), 635-640. doi:10.1042/bj3040635

Wang, J., Song, J., Gao, E., Zhang, X.-Q., Gu, T., Yu, D., et al. (2014). Induced Overexpression of Phospholemman S68E Mutant Improves Cardiac Contractility and Mortality after Ischemia-Reperfusion. Am. J. Physiology-Heart Circulatory Physiol. 306, H1066-H1077. doi:10.1152/ajpheart.00861.2013 
Wanichawan, P., Hafver, T. L., Hodne, K., Aronsen, J. M., Lunde, I. G., Dalhus, B., et al. (2014). Molecular Basis of Calpain Cleavage and Inactivation of the Sodium-Calcium Exchanger 1 in Heart Failure. J. Biol. Chem. 289, 33984-33998. doi:10.1074/jbc.m114.602581

Wanichawan, P., Hodne, K., Hafver, T. L., Lunde, M., Martinsen, M., Louch, W. E., et al. (2016). Development of a High-Affinity Peptide that Prevents Phospholemman (PLM) Inhibition of the Sodium/calcium Exchanger 1 (NCX1). Biochem. J. 473, 2413-2423. doi:10.1042/ bcj20160465

Wanichawan, P., Louch, W. E., Hortemo, K. H., Austbø, B., Lunde, P. K., Scott, J. D., et al. (2011). Full-length Cardiac Na+/Ca2+ Exchanger 1 Protein Is Not Phosphorylated by Protein Kinase A. Am. J. Physiology-Cell Physiol. 300, C989-C997. doi:10.1152/ajpcell.00196.2010

Wei, S.-k., Ruknudin, A., Hanlon, S. U., McCurley, J. M., Schulze, D. H., and Haigney, M. C. P. (2003). Protein Kinase A Hyperphosphorylation Increases Basal Current but Decreases $\beta$-Adrenergic Responsiveness of the Sarcolemmal $\mathrm{Na}+-\mathrm{Ca}$ 2+ Exchanger in Failing Pig Myocytes. Circ. Res. 92, 897-903. doi:10. 1161/01.res.0000069701.19660.14

Yap, J. Q., Seflova, J., Sweazey, R., Artigas, P., and Robia, S. L. (2021). FXYD Proteins and Sodium Pump Regulatory Mechanisms. J. Gen. Physiol. 153. doi:10.1085/jgp.202012633

Zaman, R., Islam, R. A., Ibnat, N., Othman, I., Zaini, A., Lee, C. Y., et al. (2019). Current Strategies in Extending Half-Lives of Therapeutic Proteins. J. Controlled Release 301, 176-189. doi:10.1016/j.jconrel.2019.02.016
Zhang, X.-Q., Ahlers, B. A., Tucker, A. L., Song, J., Wang, J., Moorman, J. R., et al. (2006). Phospholemman Inhibition of the Cardiac Na+/Ca2+ Exchanger. J. Biol. Chem. 281, 7784-7792. doi:10.1074/jbc.m512092200

Zhang, X.-Q., Song, J., Qureshi, A., Rothblum, L. I., Carl, L. L., Tian, Q., et al. (2002). Rescue of Contractile Abnormalities by $\mathrm{Na}+\mathrm{Ca} 2+$ Exchanger Overexpression in Postinfarction Rat Myocytes. J. Appl. Physiol. 93, 1925-1931. doi:10.1152/japplphysiol.00583.20021985

Zhang, X.-Q., Wang, J., Song, J., Ji, A. M., Chan, T. O., and Cheung, J. Y. (2011). Residues 248-252 and 300-304 of the Cardiac Na+/Ca2+ Exchanger Are Involved in its Regulation by Phospholemman. Am. J. Physiology-Cell Physiol. 301, C833-C840. doi:10.1152/ajpcell.00069.2011

Conflict of Interest: The authors declare that the research was conducted in the absence of any commercial or financial relationships that could be construed as a potential conflict of interest.

Copyright (C) 2021 Wanichawan, Skogestad, Lunde, Støle, Stensland, Nyman, Sjaastad, Sejersted, Aronsen and Carlson. This is an open-access article distributed under the terms of the Creative Commons Attribution License (CC $B Y)$. The use, distribution or reproduction in other forums is permitted, provided the original author(s) and the copyright owner(s) are credited and that the original publication in this journal is cited, in accordance with accepted academic practice. No use, distribution or reproduction is permitted which does not comply with these terms. 